University of Pennsylvania Carey Law School

Penn Law: Legal Scholarship Repository

Faculty Scholarship at Penn Law

2014

\title{
Empirical Desert, Individual Prevention, and Limiting Retributivism: A Reply
}

\author{
Paul H. Robinson \\ University of Pennsylvania Carey Law School \\ Joshua Samuel Barton \\ Sullivan \& Cromwell, NYC \\ Matthew J. Lister \\ University of Denver
}

Follow this and additional works at: https://scholarship.law.upenn.edu/faculty_scholarship

Part of the Community-Based Research Commons, Criminal Law Commons, Criminology Commons, Ethics and Political Philosophy Commons, Law and Society Commons, Law Enforcement and Corrections Commons, Social Control, Law, Crime, and Deviance Commons, and the Social Psychology Commons

\section{Repository Citation}

Robinson, Paul H.; Barton, Joshua Samuel; and Lister, Matthew J., "Empirical Desert, Individual Prevention, and Limiting Retributivism: A Reply" (2014). Faculty Scholarship at Penn Law. 485.

https://scholarship.law.upenn.edu/faculty_scholarship/485

This Article is brought to you for free and open access by Penn Law: Legal Scholarship Repository. It has been accepted for inclusion in Faculty Scholarship at Penn Law by an authorized administrator of Penn Law: Legal Scholarship Repository. For more information, please contact PennlawIR@law.upenn.edu. 
EMPIRICAL DESERT, INDIVIDUAL PREVENTION, AND Limiting RetRIBUtiVISM: A RePLY

Paul H. Robinson, "Joshua Samuel Barton** \& Matthew Lister ${ }^{* * *}$

Abstract

A number of articles and empirical studies over the past decade, most by Paul Robinson and co-authors, have suggested a relationship between the extent of the criminal law's reputation for being just in its distribution of criminal liability and punishment in the eyes of the community - its "moral credibility" - and its ability to gain that community's deference and compliance through a variety of mechanisms that enhance its crime-control effectiveness. This has led to proposals to have criminal liability and punishment rules reflect lay intuitions of justice - "empirical desert" - as a means of enhancing the system's moral credibility. In a recent article, Christopher Slobogin and Lauren Brinkley-Rubinstein (SBR) report seven sets of studies that they argue undermine these claims of empirical desert and moral credibility and instead support SBR's proposed distributive principle of "individual prevention," a view that focuses on an offender's future dangerousness rather than on his perceived desert.

The idea that there is a relationship between the criminal law's reputation for justness and its crime-control effectiveness did not originate with Robinson and his co-authors. Rather, it has been a common theme among a wide range of punishment theory scholars for many decades. A particularly important conclusion of recent Robinson studies, however, is their confirmation that this relationship is a continuous one: even small nudges in moral credibility can produce corresponding changes in the community's deference to the criminal law. This is important because it shows that even piecemeal changes or changes at the margin - as in reforming even one unjust doctrine or procedure - can have real implications for crime-control. SBR's studies, rather than contradicting the crime-control power of empirical desert, in fact confirm it. Further, SBR's studies do not provide support for their proposed "individual prevention" distributive principle, contrary to what they claim.

While SBR try to associate their principle with the popular "limiting retributivism" adopted by the American Law Institute in its 2007 amendment of the Model Penal Code, in fact it is, in many respects, just the reverse of that principle. With limiting retributivism, the Model Code's new provision sets desert as dominant, never allowing punishment to conflict with it. SBR would have "punishment" essentially always set according to future dangerousness; it is to be constrained by desert only when the extent of the resulting injustices or failures of justice is so egregious as to significantly delegitimize the government and its law. This ignores the fact that even minor departures from justice may have an important cumulative effect on the system as a whole. What SBR propose - essentially substituting preventive detention for criminal justice - promotes the worst of the failed policies of the 1960s, where detention decisions were made at the back-end by "experts, " and conflicts with the trend of the past several decades of encouraging more community involvement in criminal punishment, not less.

* Colin S. Diver Professor of Law, University of Pennsylvania.

** LL.B. (Hons.) University of Strathclyde Law School; J.D., LL.M., University of Pennsylvania Law School; Associate, Sullivan and Cromwell, New York, NY.

${ }^{* * *}$ Visiting Assistant Professor of Law, University of Denver, Sturm College of Law. 


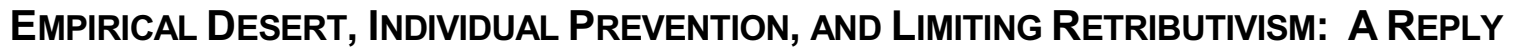

I. The Relation Between a Reputation for Doing Justice and Social and Normative Influence

A. The Moral Credibility Effect: Five Mechanisms of Social and Normative Influence

1. Avoiding Resistance and Subversion, and Promoting Assistance and Support

2. Avoiding Vigilantism

3. Enhancing Stigmatization

4. Gaining Compliance in Grey-Area Cases

5. Shaping Societal Norms and Promoting Internalization

B. Moral Credibility, Not Preventive Effectiveness

C. Anecdotal Evidence

D. The Influence of Moral Credibility in the Development of Limiting

Retributivism and Its Adoption by the American Law Institute

E. The Open Issue: Is the Moral Credibility Effect a Continuous Function?

II. Seven Studies that Purport to Undermine Empirical Desert

A. Studies Said to Undermine Empirical Desert by Refuting Its "Consensus Hypothesis"

B. Studies Said to Undermine Empirical Desert by Refuting Its "Compliance Hypothesis"

C. Studies Said to Undermine Empirical Desert by Refuting Its "Crime Control Hypothesis"

III. Conclusions, Implications \& Proposals from the Seven Studies

A. SBR's Erroneous View of the Current Punishment Theory Debates

B. SBR's Alternative Points of Criticism of Empirical Desert: "Unusually Harsh Sentences" and "Expensive Imprisonment Schemes"

C. SBR's Proposal for a Distributive Principle Based Upon "Individual Prevention" Within Limiting Retributivism

1. Irrationalities and Inconsistencies in SBR's Proposal: The Need to

Dress "Individual Prevention" as Something Other than Pure

Preventive Detention

The Failure to Define the Interrelation Among Special Deterrence,

Rehabilitation, and Incapacitation of the Dangerous

Dropping General Deterrence

Limiting "Individual Prevention" Principles to Determine Sentences

But Not Liability Rules

2. SBR's Claimed Adherence to Limiting Retributivism, and the Problem

of "Unusually Harsh Sentences"

3. SBR's Claimed Support for their "Individual Prevention" Proposal

IV. Conclusion 
In earlier writings with co-authors and in his book, Distributive Principles of Criminal Law: Who Should Be Punished How Much?, one of us argues that "empirical desert" - criminal liability and punishment rules derived from the governed community's principles of justice - would be the best among the available distributive principles. By maximizing the criminal justice system's reputation for being just, for giving an offender the punishment she deserves by society's own lights, no more and no less - by maximizing its "moral credibility" - the system gains in its normative influence over the individuals in the community. ${ }^{1}$

These ideas have gained some support and prompted some opposition. After an introduction of the theory, we consider the opposition of Christopher Slobogin and Lauren Brinkley-Rubinstein (SBR), who in a recent article present empirical studies that they claim undermine the basis for empirical desert and moral credibility, and support their own proposed distributive principle of "individual prevention," which looks to certain prevention principles within the bounds of desert, "a sort of limiting retributivism."2

\section{The Relation Between a Reputation for Doing Justice and Social and Normative Influence}

The idea that the criminal law's crime-control effectiveness is tied to its reputation for justness is hardly new with Robinson and his co-authors but rather is a well-worn view long expressed by a wide variety of writers. What Robinson and his coauthors have contributed is a recognition that these observations - on the relationship between a criminal law's moral credibility and the community's deference to it - have direct application to the ongoing debate over the proper principle for distributing criminal liability and punishment. In contributing to that debate, they have brought together into a single coherent theory ideas previously scattered across many discussions.

The theory has two elements: first, that the criminal law's reputation for justness within the community - its moral credibility - depends upon how well its rules track, or conflict, with that community's principles of justice; and, second, that such an earned reputation for justness translates into greater crime control effectiveness. ${ }^{3}$

The first element, the notion that a criminal law's reputation for justness depends upon whether it tracks or conflicts with the community's notions of justice, is perhaps self-evident and has been expressed by a diverse group of writers. In 1974, Schulhofer reports it a common view that "adherence to the common sense of justice is necessary to maintain respect for the law." In 1968, H.L.A. Hart explains the importance of following a proportionality principle by noting that to diverge from it is to risk "either confusing common morality or flouting it and bringing the law into contempt." 5 Fried explains in 1964, "It has often been said that the criminal law runs a grave risk of

1 PAUl H. Robinson, Distributive PRINCIPLES OF CRIMINAL LAW: WhO SHOULD BE PUNISHED HOW MUCH? 175-212, 248-49 (2008) [hereinafter DISTRIBUTIVE PRINCIPLES].

2 Christopher Slobogin \& Lauren Brinkley-Rubinstein, Putting Desert in its Place, 65 STAN. L. REV. 77, 122 (2013) [hereinafter SBR].

3 DISTRIBUTIVE PRINCIPLES, supra note 1 , at 175-212.

4 Stephen J. Schulhofer, Harm and Punishment: A Critique of Emphasis on the Results of Conduct in the Criminal Law, 122 U. PA. L. REV. 1497, 1513 (1974).

5 H.L.A. HART, PUNISHMENT AND RESPONSIBILITY: ESSAYS IN THE PHILOSOPHY OF LAW 25 (1968) (emphasis added). 
becoming ineffective when its prescriptions depart too widely from accepted morality." Still earlier writers have expressed the same point. ${ }^{7}$

As to the second element, Robinson and Darley identify at least five mechanisms by which the criminal law's reputation for justness can influence the community members' behavior in ways that affect the criminal justice system's effectiveness ${ }^{8}$ - mechanisms that Robinson and Darley collectively term "normative crime-control." ${ }^{9}$

\section{A. The Moral Credibility Effect: Five Mechanisms of Social and Normative Influence}

\section{Avoiding Resistance and Subversion, Promoting Assistance and Support.}

Deviating from a community's principles of justice can inspire resistance and subversion among participants in the criminal justice process -- witnesses, jurors, police, prosecutors, judges, and offenders -- where effective criminal justice depends upon their acquiescence and cooperation. Will jurors follow their legal instructions? Will criminal justice officials follow the law's rules or make up their own? Will offenders be inflamed and made more defiant by unjust punishment? Will witnesses come forward to report crimes and assist officials? In 1789, no other than Jeremy Bentham, the father of deterrence-based crime-control, observed: "When the people are satisfied with the law, they voluntarily lend their assistance in the execution: when they are dissatisfied, they will naturally withhold that assistance."10

\section{Avoiding Vigilantism}

To impose less than the punishment deserved is to invite vigilantism, as citizens undertake to provide the justice that they see the criminal justice system as failing to provide. That is, not only do they fail to assist the criminal justice system, but they undertake to become law-breakers themselves, in big ways and in little. In 1965, in speaking to both this and the previous mechanism, Andenaes explained:

6 Charles Fried, Moral Causation, 77 HARV. L. REV. 1258, 1268 (1964).

7 In 1947, Finnish criminal law theorist Salmiala argued: "[A]lthough retribution ... is not an end in itself, it is only by being presented as a just atonement that punishment can fulfill its purpose of protecting the order of justice. This is so because only in this form does the penal law agree with the people's sense of justice." JOHANNES ANDENAES, 3 THE GENERAL PART OF THE CRIMINAL LAW OF NORWAY 64 n.12 (trans. Thomas B. Ogle, 1965).

8 Paul H. Robinson \& John M. Darley, Intuitions of Justice: Implications for Criminal Law and Justice Policy, 81 S. CAL. L. REV. 1, 19-31 (2007) [hereinafter Intuitions].

9 See Paul H. Robinson, Why Does the Criminal Law Care What the Layperson Thinks Is Just? Coercive Versus Normative Crime Control, 86 VA. L. REV. 1839, 1840-41, 1861-69 (2000) (discussing normative crime-control mechanisms).

10 JeREMY Bentham, AN INTRODUCTION TO THE PRINCIPLES OF MORALS AND LEGISLATION 198-99 (1988). He refers to this effect as a "weakness" that unpopular punishment is "apt to introduce into the law." Id. 
It is often said that the sanctions imposed for criminal offenses must be in accordance with the people's sense of justice. There is some truth to this. A penal practice which is too far removed from prevailing public concepts of justice will have undesirable consequences. If the punishment is too strict, it will tend to create an aversion towards the authorities, sympathy and pity for the offender and, on the part of the offender, a feeling of injustice which can easily develop into a state of mind which counteracts the purpose of punishment. If, on the other hand, prevailing penal policy is too mild, confidence in the administration of justice can become weakened, and people may begin to take the law into their own hands. ${ }^{11}$

Similar points have been made by the U.S. Supreme Court, ${ }^{12}$ the drafters of the Model Penal Code,$^{13}$ and a host of academic writers, including Wilson \& Herrnstein and Zimring \& Hawkins. ${ }^{14}$

\section{Enhancing Stigmatization}

Some of the system's power to control conduct derives from its ability to stigmatize offenders. But the system's ability to stigmatize depends upon it having

11 ANDENAES, supra note 7, at 64-65. Elsewhere, Andenaes similarly suggests: "Just retribution, according to this school of thought, is not the goal of punishment; it is the means which, socio-psychologically speaking, is most effective in securing obedience." And: "When the penalties are not reasonably attuned to the gravity of the violation, the public is less inclined to inform the police, the prosecuting authorities are less disposed to prosecute and juries are less apt to convict." Johannes Andenaes, The General Preventive Effects of Punishment, 114 U. PA. L. REV. 949, 971 n.42 (1966).

12 "The instinct for retribution is part of the nature of man, and channeling that instinct in the administration of criminal justice serves an important purpose in promoting the stability of a society governed by law. When people begin to believe that organized society is unwilling or unable to impose upon criminal offenders the punishment they 'deserve,' then there are sown the seeds of anarchy-of self-help, vigilante justice, and lynch law." Furman v. Georgia, 408 U.S. 238, 308 (1972) (Stewart, J., concurring).

13 "Failure to insure that the conduct that is the occasion for sentence controls the severity of the sentence violates the widely held sense that penalty should be proportionate to the magnitude of an offense, and risks nullification of the law by those who feel impelled to administer a system that can be characterized as just and fair." MODEL PENAL CODE AND COMMENTARIES, PART 1: GENERAL PROVISIONS $\S \S 6.01$ TO 7.09, at $\S 6.07 \mathrm{cmt} .2$ (1985) [hereinafter MPC COMMENTARIES].

14 See, e.g., JAMES Q. WILSON \& RichaRd J. HERRNSTEIN, CRIME AND Human NATURE 506-07 (1985) ("Legislatures and courts are the formal instruments for setting just penalties, but they must conform to the prevailing consensus on what is fair or the legal system loses legitimacy. Deviating from the consensus in either direction damages society. An excessively cruel system of law may control the behavior of its citizens even more strictly than a just one, but people will surely hate it, may resist submitting to it, and, if the occasion ever arises, may try to overthrow it. Too lax a system of law will fail to satisfy the public desire for justice and thereby risk vigilantism. It will fail to deter and to educate morally. And it will impair the public's sense of respect for the law."); FRANKLIN ZIMRING \& GORDON HAWKINS, DETERRENCE 62 (1973) ("[T]he employment of harsh penalties leads to nullification of the law by virtue of the fact that, at various levels or stages in the criminal justice process, there is a deliberate refusal fully to implement the statutes to which the severe punishments are attached."). 
moral credibility with the community - the extent to which its announcements of what is criminal match what the community sees as morally condemnable. In 1958 Henry Hart wrote:

On the sheerly pragmatic ground of the need for equipping the proposed social order with adequate tools to discourage undesired conduct, a responsible constitution-maker assuredly would hesitate long before rejecting [desert as a distributive principle] in favor of [rehabilitation]. . . . A constitution-maker . . . will be likely to regard the desire of the ordinary man to avoid the moral condemnation of his community, as well as the physical pains and inconveniences of punishment, as a powerful factor in influencing human behavior which can scarcely with safety be disposed with. ${ }^{15}$

Here is how the Model Penal Code Commentaries put it in 1985:

[T]he effectiveness of criminal sanctions depends partly on the social condemnation they embody and . . if severe penalties are imposed for trivial offenses the link between condemnation and sanction will be destroyed. ${ }^{16}$

A hundred years earlier, James Fitzjames Stephen made a similar point:

I think that whatever effect the administration of criminal justice has in preventing the commission of crimes is due as much to [the fear of community condemnation] as to any definite fear entertained by offenders of undergoing specific punishment. ... [ [ am] of opinion that this close alliance between criminal law and moral sentiment is in all ways healthy and advantageous to the community. ${ }^{17}$

\section{Gaining Compliance in Grey-Area Cases}

If it has earned "moral credibility" with the community it governs, the criminal law can gain compliance in grey-area cases, cases in which the propriety of certain conduct is unsettled or ambiguous in the mind of the actor. Even if it is not obvious to a person why such conduct is condemnable, the person is more likely to defer to the law's commands if it has earned a reputation for reliability assessing blameworthiness. As Gorecki wrote in 1979:

15 Henry M. Hart, Jr., The Aims of the Criminal Law, 23 LAW \& CONTEMP. PROB. 401, 408-09 (1958).

16 MPC COMMENTARIES, supra note 13 , at 4.

17 JAMES FitZJAMES STEPHEN, 2 HISTORY OF THE CRIMINAL LAW OF ENGLAND, at 81 (1883). One writer notes that, while Stephen is actually a retributivist, he seems to adopt "a disguised utilitarian position." For Stephen, retributive punishment is justified partly on the basis of empirical desert's second crime-control mechanism, in that such punishment "provides an orderly outlet for emotions that, denied it, would express themselves in socially less acceptable ways." This is a retributive position with strong "utilitarian underpinnings." HERBERT L. PACKER, THE LIMITS OF THE CRIMINAL SANCTION 37 (1968). 
An excessively harsh punishment is unjust and, therefore, both its enactment on the criminal code and its infliction by criminal courts are void of persuasive power. Worse than that, they seem to be counterproductive: Seeing inequitable punishment may free incensed observers from self-censure of their own actions, rather than prompting compliance, and thus increase transgressive behavior ... If the society considers a penalty as unjustly harsh, its application brings sympathy and friendliness for the offender. These feelings may easily become, owing to an association of images, extended to the prohibited acts themselves; which undermines disgust for crime and, sometimes, even results in glorifying the criminal and in favoring harmful behavior. At the same time, by generating resentment in the society, excessively harsh punishments undermine the legitimacy of the punishing agents - respect for and trust in them - and thus further erode the persuasive power of criminal justice. ${ }^{18}$

\section{Shaping Societal Norms and Promoting Internalization}

Finally, deviations from empirical desert also undermine crime control by limiting the law's access to one of the most powerful forces for gaining deference: influencing societal norms. Indeed, this may be the criminal law's most important real-world effect: its ability to assist in the building, shaping, maintaining, and internalizing of these moral norms. Andenaes in 1952 explains that

punishment as a concrete expression of society's disapproval of an act helps to form and to strengthen the public's moral code and thereby create conscious and unconscious inhibitions against committing crime. . . . To the lawmaker, the achievement of [moral] inhibition and habit is of greater value than mere deterrence. For these apply in cases where a person need not fear detection and punishment, and they can apply without the person even having knowledge of the legal prohibition. ${ }^{19}$

The extent of the criminal law's effectiveness in all these respects -- in avoiding resistance and subversion of an unjust system, in avoiding vigilantism sparked by a system that fails to do justice, in bringing the power of stigmatization to bear, in gaining compliance in borderline cases through deference to its moral authority, and in facilitating, communicating, and maintaining societal consensus on what is and is not condemnable -- depends on the degree to which the criminal law has earned moral credibility with the citizens it governs. Moral credibility is enhanced if the distribution of criminal liability is perceived as "doing justice," that is, if it assigns liability and punishment in ways that the community perceives as morally just, so-called "empirical desert." Conversely, the system's moral credibility, and therefore its crime-control effectiveness, is undermined if it deviates from the community's perceptions of just desert.

18 J. GORECKI, A THEORY OF CRIMINAL JUSTICE 25 (1979) (internal citation and quotation marks omitted).

19 Johs Andenaes, General Prevention--Illusion or Reality?, 43 J. CRIM. L., C. \& P.S. $176,179-80$ (1952). 


\section{B. Moral Credibility, Not Preventive Effectiveness}

Notice that the crime-control influence here arises from the criminal law's moral credibility - its perceived justness by the community - not its perceived preventive effectiveness. ${ }^{20}$ Consider the Supreme Court's Rummel case, for example, in which Rummel's fraudulently obtaining $\$ 120$ for fixing an air conditioner that he had no intention of fixing, earned him a life sentence because of his prior offenses of similar seriousness. ${ }^{21}$ Many people may well be happy with the preventive benefits that flow from offender Rummel getting life in prison so he cannot again pull a minor theft or fraud scheme. Yet no one will think that he deserves such punishment for his $\$ 120$ airconditioner repair fraud, even after taking account of his several previous such offenses that triggered his "three-strikes" sentencing. Indeed, we know from empirical studies that subjects thought his offense, together with his prior record, put his moral blameworthiness as somewhere between that of a minor assault causing bruising and a burglary in which a microwave was taken from a house, for a sentence of 3.1 years ${ }^{22}-$ not life in prison. That is, people see Rummel's life sentence as seriously unjust, far beyond what his blameworthiness deserved, even though they might well appreciate that it will prevent him from committing (perhaps many) other offenses in the future.

The preventive gain may have crime-control value but it also undermines the law's moral credibility and thus also has a crime-control cost. It is only the law's reputation for tracking moral condemnability, not its preventive-efficiency reputation, that has the normative crime-control effects described above: avoiding the resistance and subversion of an unjust system, avoiding vigilantism sparked by a system that fails to do justice, gaining compliance in borderline cases through deference to its moral authority, bringing the power of stigmatization to bear, and facilitating, communicating, and maintaining societal consensus on what is and is not condemnable. These crimecontrol mechanisms all depend upon the criminal law's justness, not its preventive detention effectiveness.

Notice that the system's ability to trigger these mechanisms of social and normative influence does not depend upon a general satisfaction or dissatisfaction with the criminal justice system but upon a very specific kind of satisfaction or dissatisfaction with it: it depends upon how well the law accurately reflects the community's judgements about moral blameworthiness. That is, there is a difference between, for example, a perception that a system's procedures are fair - which may lead to what Tom Tyler calls a perceived "legitimacy" of the system - and a perception that its results are just - that its adjudications of liability and punishment in specific cases give each defendant what he deserves. ${ }^{23}$

This follows because a perception of fair procedures does not trigger many of moral credibility's mechanisms of influence described above. Even a perception that

20 Of course, a "legal system" with very little or no effectiveness in preventing crime is also unlikely to engender compliance, but this limiting case is not the one we face in most societies, and need not concern us here.

21 Rummel v. Estelle, 445 U.S. 263, 266 (1980).

22 Paul H. Robinson, Geoffrey P. Goodwin, \& Michael D. Reisig, The Disutility of Injustice, 85 N.Y.U. L. REV. 1940, at 1972 Table 3 (2010) [hereinafter Disutility of Injustice].

${ }^{23}$ See generally Josh Bowers \& Paul H. Robinson, Perceptions of Fairness and Justice: The Shared Aims and Occasional Conflicts of Legitimacy and Moral Credibility, 47 WAKE FOREST L. REV. 211 (2012) [hereinafter Fairness and Justice]. 
the system's procedures are fair will not create a perception that the system accurately reflects what conduct is truly morally condemnable and what deserves stigmatization. ${ }^{24}$ A system seen as having fair procedures may well help inspire assistance rather than resistance, but there is no reason it would persuade people to see its liability and punishment judgements as a reliable indicator of what is morally condemnable. (If perceptions of legitimacy can help gain compliance and reduce resistance and subversion, as Tyler claims, then system designers ought to promote legitimacy. ${ }^{25}$ But even Tyler concedes that the effect of moral credibility from the justness of results is greater than that of "legitimacy" from fair procedures. ${ }^{26}$ )

\section{Anecdotal Evidence}

The many writers quoted above explaining aspects of the moral credibility effect - greater deference with greater moral credibility, reduced deference with lesser moral credibility - came to those conclusions not from a battery of social science studies but rather from their observations of how the world around them seemed to work, how people seemed to react. Part of that experience and the common sense they applied to it, includes anecdotal evidence: for example, a general perception that societies in which the citizens hold the criminal law in low regard - as being indifferent to justice are societies in which those citizens are less likely to support, comply, and defer to the criminal law, and more likely to ignore, resist, or subvert it.

The notoriously unjust Soviet criminal justice system, ruled by coercion and threat and tainted by politics and ideology, earned little moral credibility (or legitimacy) with the public. ${ }^{27}$ As Peter Solomon concludes, "Soviet experience demonstrates that indiscriminate and coercive use of the criminal law approaching naked repression discredits both the law and the regime that sponsors it." ${ }^{28}$ Russian crime rates

24 The latter are perceptions that are at the core of why many of the normative crimecontrol mechanisms work (certainly mechanisms three, four, and five, and possibly two noted in the text).

25 For a general comparison of the two, see Fairness and Justice, supra note 23.

26 TOM R. TYLER, WHY PEOPLE OBEY THE LAW 59 (2006) (reporting the relative weight of the factors shaping compliance with the law as: morality 0.33 , legitimacy 0.11 , deterrence 0.02 ).

27 See, e.g., Robert A. Kushen, The Death Penalty and the Crisis of Criminal Justice in Russia, 19 BROOK. J. INT'L L. 523 (1993); PETER H. SOlOMON, SOVIET CRIMINAL JUSTICE UNDER STALIN (1996). continues:

28 Peter H. Solomon, Soviet Criminal Justice Under Stalin 463 (1996). Solomon

During the collectivization campaign Soviet legal officials reduced the use of legal procedures to the point where their actions resembled those of other agents of police and local power. As a result the authority and status of law was called into question, and much effort expended later on to restore the law to its normal footing. Less obviously, this account of the history of criminal justice under Stalin reveals that in an authoritarian regime the criminal sanction was also limited by capacity for enforcement. When Stalin tried to use the criminal law for purposes and in ways not accepted by its enforcers (legal officials, police, and others) or call for penalties that struck them as too severe, the result was evasion, resistance, and inconsistent enforcement. These consequences followed Stalin's extensions of the criminal law (e.g., to the policing of defective goods production and the regulation of the labor force); his recriminalization of

(continued...) 
increased under Soviet rule. ${ }^{29}$ Further, when overwhelming state control was lost with the collapse of the Soviet Union, crime spiked. ${ }^{30}$ Having destroyed its moral credibility with the community, and having had no time or capability to establish credibility when the old system collapsed, the new system had little ability to control. The system had lost its access to the forces of normative and social influence. When it also lost its power of coercive police control, it was left with little or nothing.

Of course, the reaction to the Soviet Union criminal justice system may have been a product of both the unfairness of its procedures and the unjustness of its results. That is, it could be a deficit in both areas that is doing the work here. But consider another bit of anecdotal evidence of the sort that has probably affected people's thinking on the issue: U.S. Prohibition. By having the criminal law enforce a law that prohibited what most people thought was not conduct so morally condemnable as to deserve criminalization, ${ }^{31}$ the reform spoke directly to the law's moral credibility with the community. The Prohibition laws were widely ignored, by the population and it leaders, but that was not the end of it. Lawbreaking of all sorts increased, and not just that related to the drinking of alcohol. ${ }^{32}$ If the law could be so wrong about seeing alcohol consumption as criminally condemnable, what else had it got wrong?

Alcohol consumption initially decreased when Prohibition first took effect probably due to decreased supply and increased price ${ }^{33}$ - but quickly rebounded, rising to 60-70 percent of pre-Prohibition levels despite the fact that it was now illegal. ${ }^{34}$ Instead of resulting in mainstream compliance or in changing community norms, the law and its common disregard led to "widespread public disenchantment" with the criminal

28 (...continued)

old offenses (abortion and juvenile delinquency); and his mandating of the sharp increases in punishment for theft (in 1932 and in 1947). The point is that even a dictator whose authority is not limited by institutional checks faces limitations on his power stemming from the capacity of his government to enforce his decisions.

Id.

29 See, e.g., Andrew Stickley \& Ilkka Henrik Makinen, Homicide in the Russian Empire and Soviet Union: Continuity or Change?, 45 BRIT. J. CRIMINOLOGY 647, 658 (2005).

30 See, e.g., JONATHAN WEILER, HUMAN RIGHTS IN RUSSIA: A DARKER SIDE OF REFORM 2 (2004); Christopher T. Ruder, Individual Rights Under the New Russian Constitution: A Practical Framework for Competitive Capitalism or Mere Theoretical Exercise?, 39 ST. LOUIS U. L.J. 1429, 1456 n.156 (1995) (discussing sharp increase in crime); Jane Weaver, Are Institutions Doing Their Job? Kleptocracy and Democracy, 90 AM. SOC'Y INT'L L. PROC. 83 (1996) (discussing rampant crime in Russia).

31 The $18^{\text {th }}$ Amendment was brought about primarily by single-issue voting by religious organizations and some of the recently-enfranchised women (who bore the brunt of domestic violence seen as fueled by drunkenness). See EDWARD BEHR, PROHIBITION: THIRTEEN YEARS THAT CHANGED AMERICA 50-67 (1996).

32 See infra notes 36-39 and accompanying text.

33 Jeffrey A. Miron \& Jeffrey Zwiebel, Alcohol Consumption During Prohibition, 81 AM. ECON. REV. 242-47, at 246 (1991) ("Changes in consumption during Prohibition were modest given the change in price. This suggests that legal deterrents had little effect on limiting consumption outside of their effect on price. Social pressure and respect for the law did not go far in reducing consumption during Prohibition.").

${ }^{34}$ Id. at 242 ("We find that alcohol consumption fell sharply at the beginning of Prohibition, to approximately 30 percent of its pre-Prohibition level. During the next several years, however, alcohol consumption increased sharply, to about 60-70 percent of its preProhibition level."). 
law. ${ }^{35}$ With this came increased law-breaking of all sorts. ${ }^{36}$ Violent crime increased throughout the Prohibition period. ${ }^{37}$ Per capita homicide rates drastically increased nationwide even when alcohol consumption was decreasing or unchanging, ${ }^{38}$ and this included an increase in homicides entirely unrelated to the sale or consumption of alcohol. ${ }^{39}$

\section{The Influence of Moral Credibility in the Development of Limiting Retributivism and Its Adoption by the American Law Institute}

Just a few years ago, the American Law Institute, for the first time since its 1962 promulgation, amended the Model Penal Code, specifically its Section 1.02(2), which sets out its distributive principles for sentencing. The Model Code drafters have always been highly instrumental in their formulations, thinking of the Code as being primarily in the business of preventing crime rather than in the business of giving deserved punishment for its own sake (deontological desert). The drafters explain that the "dominant theme" of their approach is unequivocally "the prevention of offenses." 40

The Model Code's approach to sentencing is basically utilitarian or consequentialist; the justification for penal sanctions is perceived to be the prevention of social harm, and the choice of sanction in an individual case is to be guided by that objective, subject to the limiting demands of other values that the Code respects. ${ }^{41}$

They explain that the Model Code "is based on the premise that 'desert' alone is not a sufficient justification for punishment. It is inhumane and morally unacceptable for

35 Id. at 242 ("[T]he inability to restrict the illegal trade and the inevitable accompanying corruption eventually led to widespread public disenchantment with Prohibition.").

36 See Charles Hanson TOWNe, The Rise And Fall of PROHIBITION: The Human Side OF WhAT THE EIGHTEENTH AMENDMENT AND THE VOLSTEAD ACT HAVE DONE TO THE UNITED STATES 159-62 (1923) (reciting statistics showing significant increases in homicide, theft and burglary, assault and battery, drug addiction, drunk driving, and drunkenness and disorderly conduct); MaRk Thornton, Cato InSt., Policy Analysis No. 157: AlCOHOl Prohibition WAS a Failure 1, 5-8 (July 17, 1991) (reciting statistics showing a rise in criminal activity, noting that "crime increased and became 'organized'; the court and prison systems were stretched to the breaking point; and corruption of public officials was rampant").

${ }_{37}$ See, e.g., Jeffrey A. Miron, Violence and the U.S. Prohibitions of Drugs and Alcohol, 1 AM. L. \& ECON. REV. 78, 91-92 (1999).

${ }^{38}$ See Jeffrey A. Miron, Violence and the U.S. Prohibitions of Drugs and Alcohol, 1 AM. L. \& ECON. ReV. 78-114 (1999); Jeffrey A. Miron, An Economic Analysis of Alcohol Prohibition, 28 J. DRUG ISSUES 741(1998); Miron \& Zwiebel, supra note 33; Gary F. Jensen, Prohibition, Alcohol, and Murder: Untangling Countervailing Mechanisms, 4 HOMICIDE STUD. 18-36 (2000).

${ }_{39}$ Mark Asbridge \& Swarna Weerasinghe, Homicide in Chicago from 1890 to 1930: Prohibition and its Impact on Alcohol- and Non-alcohol-related Homicides, 104 ADDICTION 35564 (2009) (finding that the rate of non-alcohol-related homicides increased by $11 \%$ ).

40 Model Penal Code $\S 1.02$ explanatory note (1962). See also Model Penal Code AND COMMENTARIES, PART 1: GENERAL PROVISIONS $\S \S 1.01$ to 2.13 , at $\S 1.02 \mathrm{cmt}$. 2(a) (1985) (noting that the Model Penal Code "affirms and articulates the dominant preventive purpose of the penal law"); id. at cmt. 3(a) (making the same point).

${ }^{41}$ MPC COMMENTARIES, supra note 13 , at 2. 
society formally to inflict great suffering on individuals unless some social purpose is served by that suffering." ${ }^{\text {"2 }}$ Thus, the Model Code is designed "to exclude punishment imposed without regard to the demands of crime prevention, leaving no room for dispositions motivated merely by vindictive or retributive considerations." ${ }^{43}$

Yet in the new amendment, the Model Code gives overriding dominance to desert. The new Section 1.02 (2)(a)(i) requires that punishment be "within a range of severity proportionate to the gravity of offenses, the harms done to crime victims, and the blameworthiness of offenders" - the classic elements constituting desert. Subsection (2)(a)(ii) allows the traditional coercive crime control principles to be consulted only "within the boundaries of sentence severity permitted in subsection (a)(i)" - in other words, they can never violate desert. ${ }^{44}$

Why would such committed instrumentalists as the Model Penal Code drafters, suddenly feel obliged to limit the principles of coercive crime control so as to never violate desert? Perhaps they were touched by the deontological arguments of the moral philosophers. But they might also have come to a stronger appreciation - even stronger than the initial Model Code drafters - of the instrumentalist crime-control benefits of abiding by the community's sense of justice and of the crime-control costs of conflicting with it.

In fact, the drafters of the Amendment are explicit about their instrumentalist interest in the practical effects of deviating from community views:

Maintaining the moral legitimacy of any system of law is an intrinsic good, but one that also holds instrumental dimensions. Negative consequences of widespread distrust of the criminal-justice system include reduced inclinations to abide by the law, to cooperate with officials during a criminal investigation, and even to report serious criminal victimizations in the first instance. ${ }^{45}$

"The revised Code is intended to encourage the pursuit of utilitarian ends ... Proportionality limitations do not demean, but legitimate, investment in a strong utilitarian agenda." ${ }^{.46}$ In the context of sentencing for drug offenses, they note the need to take account of "the heavy costs suffered in disproportionalities in punishment and societal perceptions of the illegitimacy of the criminal law. ${ }^{47}$

This sensitivity to community views should surprise no-one. Indeed, it is implicit in the Code's adoption of "limiting retributivism," which, despite its deontologically sounding label, is historically grounded in an appreciation of both the philosophical value of deontological desert and the instrumentalist costs of deviating from societal intuitions of justice (empirical desert).

As Norval Morris, one of the fathers of limiting retributivism, explains, "The criminal law has general behavioral standard-setting functions; it acts as a moral

42 Id. at 16.

43 Model Penal Code and Commentaries, Part 1: General Provisions $\S \S 1.01$ to

2.13, at $\S 1.02 \mathrm{cmt}$. 3(a) (1985).

44 Model PenAl Code: Sentencing $\S 1.02(2)(a)$ (approved May 16, 2007).

45 Model Penal CodE: SENTENCING $§ 1.02(2)$ reporter's note, cmt. o (Tentative Draft No.

1, 2007).

46 Model Penal Code: Sentencing $\S 1.02(2) \mathrm{cmt}$. b (Tentative Draft No. 1, 2007.) (emphasis added).

47 Model Penal Code: Sentencing: Plan for Revision 50 (Jan. 24, 2002). 
teacher." ${ }^{48}$ Community views play a central role in the operation and justification of limiting retributivism. The limit on the amount of punishment that may be imposed is defined by Morris in empirical desert terms: "the maximum of punishment that the community exacts from the criminal to express the severity of the injury his crime inflicted on the community as a condition of readmitting him to society." And the offender must suffer a minimum level of punishment "if he is to be reaccepted as a member of society." ${ }^{49}$ Overall, "[r]etribution ... not only limits the worst suffering we can inflict on the criminal, but also sometimes dictates the minimum sanction a community will tolerate." ${ }^{.0}$

Morris' limiting retributivism has "important roots" in the works of Herbert Packer, H.L.A. Hart, and Lord Longsford. ${ }^{51}$ Like Morris, each of these authors made room for the operation of both desert and utilitarian principles. Again, however, each of them justified their adoption of desert partly on instrumentalist grounds.

Packer recognized that "limits need to be placed on the adoption of the utilitarian stance," ${ }^{\prime 2}$ and took the view that "blameworthiness as a prerequisite to the imposition of punishment" represented one "important limiting principle." ${ }^{53}$ Why would Packer, a committed utilitarian, ${ }^{54}$ adopt desert principles of this sort? The answer lies in the associated instrumentalist benefits..$^{55}$ In particular, Packer thought that crime-control interests are best served by a penal system that tracks societal notions of justice. Any benefits produced by a classic utilitarian crime-control system, he says,

must be weighed against the damage that will be done to the criminal law as carrier of our shared morality unless its reach is limited to blameworthy acts. Unjust punishment is, in the end, useless punishment. It is useless both

48 NORVAL MORRIS, THE FUtURE OF IMPRISONMENT 78 (1974) (emphasis added).

49 Id. at 74 (emphasis added). Elsewhere Morris explains, "We use only the 'guilty' to [deter others]; they have deserved this role and to play it facilitates their readmission to the group." Unjustly severe punishment is "to the extent of that excess, punishment of the 'innocent,' inhibiting [the offender's] readmission to society." Id. at 75 (emphases added).

50 MORRIS, supra note 48 (emphasis added).

51 Model PenAl Code: Sentencing 14 (Preliminary Draft No. 1, 2002); see also Model PENAl Code: SentencING: PlAN FOR REVISION 21 (2002) ("Retribution can also operate as an important limitation upon utilitarian goals, as posited in the work of H.L.A. Hart, Herbert Packer, and Norval Morris."). The American Law Institute refers to the following materials as "important precursor works" to Morris' theory of limiting retributivism: HART, supra note 5; HERBERT L.

PACKER, THE LIMITS OF THE CRIMINAL SANCTION (1968); FRANK A. PAKENHAM (LORD LONGFORD), The IDEA Of Punishment (1961). Model Penal Code: Sentencing 14 n.19 (Preliminary Draft No. 1, 2002).

52 PACKER, supra note 51, at 63.

53 Id. at 66.

54 Id. at 5 ("[My] book is somewhat old-fashioned [] in that it seeks to apply utilitarian principles to larger problems than those that today seem to interest most professional philosophers. In both substance and method the shades I invoke...are those of Bentham and Mill."); id. at 66 ("The case for an essentially preventive view of the function of criminal law is unanswerable; anything else is the merest savagery.")

55 As he explains: "The view I take of culpability in the justification for punishment is an instrumental one. I see this limitation on the utilitarian position as desirable not for any inherent quality that it possesses but because it serves ends that I think require attention in a criminal system." Id. at 67. 
because it fails to prevent crime and because crime prevention is not the ultimate aim of the rule of law. ${ }^{56}$

He thought "the subtle process of value reinforcement through the rites of criminal stigmatization" played a particularly significant role in crime-control - "probably more significant[]," in fact, than the threat of punishment itself. ${ }^{57}$ Thus, for Packer, "the singular power of the criminal law" lies not only in its coercive power but also in its "conscious and unconscious moralizing and habit-forming effects that go far beyond the crassness of a narrowly conceived deterrence. ${ }^{58}$ Ultimately, "[a] criminal law system cannot attract and retain the respect of its most important constituents - the habitually law-abiding - unless it is seen to be fair." ${ }^{59}$ In summary, then, Packer sees the moral credibility of the system - its reputation for tracking community views of justice - as crucial to its crime-control effectiveness.

H.L.A. Hart is also thought to have influenced the emergence of limiting retributivism. Like Packer, Hart fully embraced the idea of a mixed theory of punishment. ${ }^{60}$ In particular, he recognized that the use of coercive crime-control mechanisms might sometimes be limited by desert principles. ${ }^{61}$ Why this concession to desert? Again, Hart's reasons include the instrumentalist. He believed that all offenses hold "a distinct place in a commonsense scale of gravity," and that the precise placement of each offense on this scale depends on its "relative moral iniquity and harmfulness." ${ }^{\text {26 }}$ As noted previously, he also believed that the criminal law should reflect this scale of gravity, "for where the legal gradation of crimes expressed in the relative severity of penalties diverges sharply from this rough scale, there is a risk of either confusing common morality or flouting it and bringing the law into contempt."63 Finally, Hart knew that an unjust system can inspire resistance and subversion among

56 Id. at 65. See also id. ("What could be more certain to undermine one's sense that it is important to avoid [harming others] than the knowledge that, if one inflicts harm, he may be punished even though he cannot be blamed for having done so?").

57 Id. at 44. See also id. (emphasis added) ("The sense of fitness...that we feel at the spectacle of merited suffering becomes a prop for our own sense of identification with law-abidingness. This is, then, an important part of the utility of punishment:" it helps "reinforce[] individual rectitude.")

58 Id. at 70.

59 ld.

60 HART, supra note 5, at 3 ("[D]ifferent principles... are relevant at different points in any morally acceptable account of punishment."); id. at 10 ("[A]fter stating [the] general aim or value [of punishment] we should enquire whether there are any and if so what principles limiting the unqualified pursuit of that aim or value. Just because the pursuit of any single social aim always has its restrictive qualifier, our main social institutions always possess a plurality of features which can only be understood as a compromise between partly discrepant principles.").

61 In his own words: "There are many different ways in which we think it morally incumbent on us to qualify or limit the pursuit of the utilitarian goal by the methods of punishment. [W] . . . limit punishments in order to maintain a scale for different offences which reflects, albeit roughly, the distinction felt between the moral gravity of these offences. Thus we make some approximation to the ideal of justice of treating morally like cases alike and morally different ones differently." $I d$. at 80 .

62 Id. at 25.

63 Id. 
actors whose acquiescence and cooperation is required for the system to properly function. As he puts it, "administrative and judicial officers might refuse to give effect to the use of 'punishment' in [unjust] circumstances and would hence 'nullify' it."64

Lord Longsford's work also foreshadowed the emergence of limiting retributivism. Like Morris, Longsford would pursue classic utilitarian crime-control mechanisms only within the limits of desert, ${ }^{65}$ but his reasons are entirely consequentialist. Desert "should be retained in view of the probable damage to morality in general and law-abidingness in particular if it disappeared." ${ }^{\prime 66}$ "[N]either deterrence nor reform can 'do their stuff properly' unless the penalty is felt to be just." ${ }^{67}$ The people of the community "are never likely to support in their hearts a sentencing policy" that dramatically deviates from desert. ${ }^{68}$ Instead, such a policy would "discredit[] the law and diminish[] the sanctions which operate against crime."69

In summary, then, the theory of limiting retributivism has important roots in empirical desert thinking. Its adoption by the American Law Institute, together with its general popularity, suggest a growing appreciation of the crime-control benefits associated with a morally credible criminal justice system, as well as the crime-control costs of undermining that credibility.

\section{E. The Open Issue: Is the Moral Credibility Effect a Continuous Function?}

The macro-effect of reduced moral credibility undermining deference to the law, to which all of the writers quoted above refer, cannot be seriously disputed. Yet until recently there remained an important open issue for social and legal reformers: is the moral credibility effect something that is seen only as between two criminal justice systems of dramatically disparate reputations, as between the Soviet and Western criminal justice systems, or even between the US and (say) Mexico (U.S. crime rates are significantly below average among the countries in the world ${ }^{70}$ ), or even between a

64 Id. at 76.

65 PAKENHAM (LORD LONGSFORD), supra note 51, at 61 ("Retribution, in short, provides a justification for some punishment and sets a limit to the amount of punishment justifiable. But deterrence and reform are the main factors which society should take into account in deciding how far society should exercise its right of punishment when passing sentence."); id. at 62 (noting that desert "provides the right of society to punish and sets the limit to the amount of punishment"); id. at 33 ("Retribution is not a guiding principle in the choice and administration of a punishment; but it has still a negative function... [l]t is a sense of just retribution which rules out penalties conspicuously out of proportion to the crime committed.") (quoting M. Grünhut, Penal Reform (1948)).

$66 \quad$ Id. at 57.

67 Id. at 61.

68 ld. at 55.

69 Id.

70 For example, the U.S. murder rate of 4.2 per 100,000 people is lower than that most countries in the world, and only about sixty percent of the world's overall rate - almost 7 per 100,000. In contrast, Africa averages a murder rate of 17, South America 20, and Central America 28.5. And many individual countries in the world's lower-crime regions have noticeably high murder rates. Indonesia has a rate of 8.1, Russia 10.2, North Korea 15.2, and Greenland 19.2. Many countries have murder rates in the $30 \mathrm{~s}$ and $40 \mathrm{~s}$ or higher. Honduras, the record holder, has a rate of more than 91. UNITED NATIONS OFFICE ON DRUGS AND CRIME, HOMICIDE 
US with Prohibition and one without Prohibition? Or is the relationship between moral credibility and community deference a continuous function, in which marginal adjustments to reputation will produce correspondingly marginal adjustments to deference?

The question is an important one for legal reformers because it tells whether there is a crime-control benefit in improving the criminal law's current moral credibility marginally, as by reforming one doctrine that conflicts with empirical desert and then another. Similarly, does each new doctrine that conflicts with community notions of justice incrementally undermine the law's moral credibility and thereby its crime-control effectiveness? It was this important question that appears to be answered by recent studies, by Janice Nadler and by others ${ }^{71}$ and, most recently, by Robinson and coauthors in their article, The Disutility of Injustice. ${ }^{72}$

The studies show that there is indeed a continuous relationship, rather than some odd step-function. Marginal changes in the criminal law's reputation do generate corresponding marginal changes in deference to it. ${ }^{73}$ That is, the difference between the Soviet and the U.S. situations was simply part of a continuous relationship between moral credibility and deference, as represented in the graphic below.

70 (...continued)

STATISTICS 2012, available at http://www.unodc.org/unodc/en/data-and-analysis/homicide.html.

71 Janice Nadler, Flouting the Law, 83 TEX. L. REV. 1399 (2005); Erich J. Greene, Effects of Disagreements Between Legal Codes and Lay Intuitions on Respect for the Law iv (June 2003) (unpublished Ph.D. dissertation, Princeton University) (on file with Mudd Library, Princeton University).

72 Disutility of Injustice, supra note 22.

73 See, e.g., id. at 1997-2011 (finding that test subjects were less likely to assist and defer to the criminal law after being exposed to a variety of cases that produced results inconsistent with their intuitions of justice); Janice Nadler, Flouting the Law, 83 TEX. L. REV. $1399,1410-26$ (2005) (finding that test subjects were more likely to engage in criminal activity and juror nullification after being exposed to various injustices in the criminal justice system). 


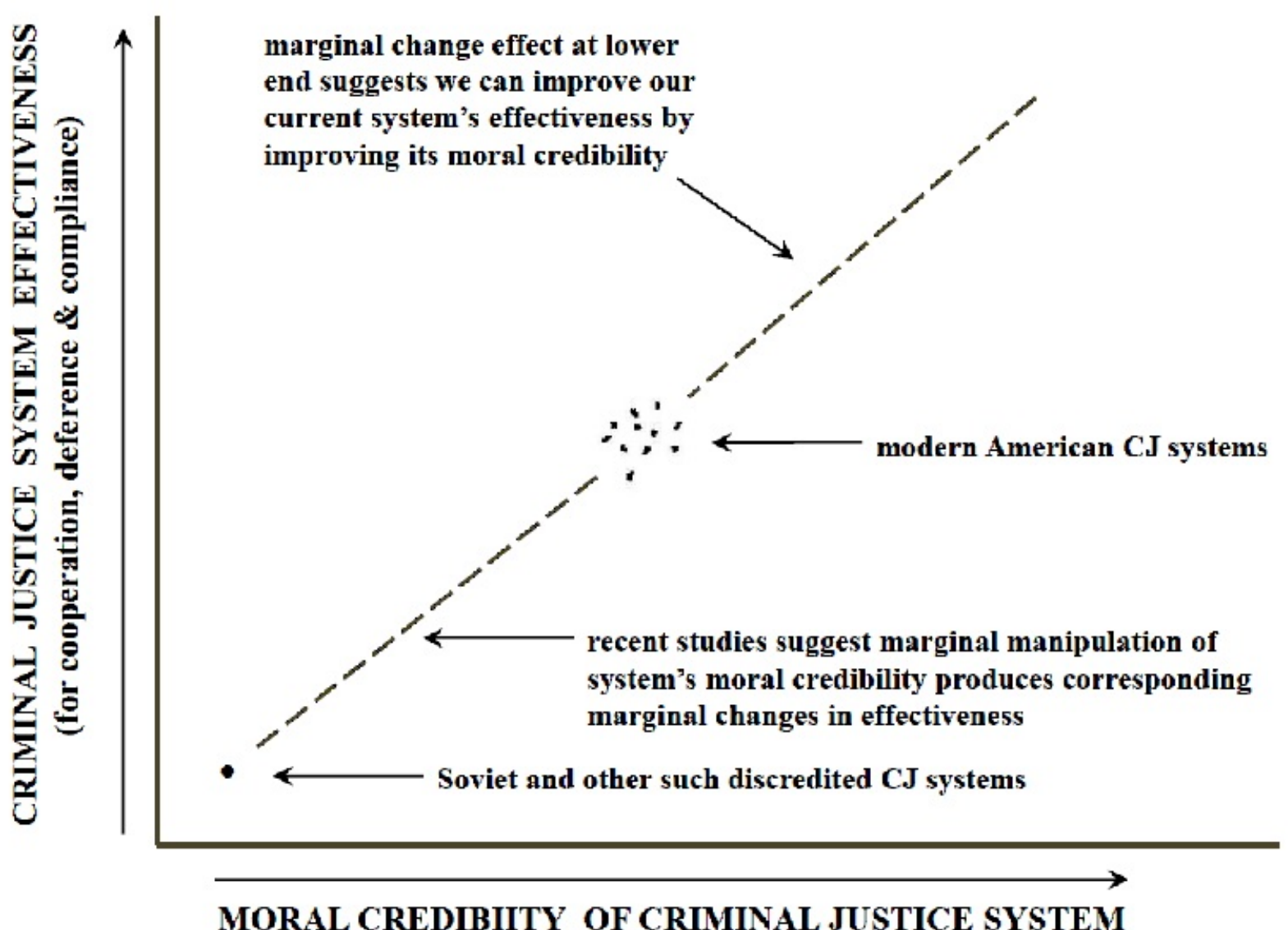

This is good news for experimental researchers, because it is essentially impossible to produce in a social science lab the kind of shifts in moral credibility that one sees between the U.S. and the USSR or Belarus or even Mexico. Subjects come to the lab with well-developed views of the criminal justice system's justness, views built up over decades of reports about the system in which they live. Indeed, it is somewhat surprising that during their hour in the lab the experimenters can get subjects to modify their views at all on the criminal justice system's moral credibility. The experimental work has shown, however, that the careful and creative researcher can indeed nudge those views toward disillusionment. And what the studies show is that even this nudge, as minor a shift as it is, can nonetheless produce corresponding shifts in the subjects' willingness to defer.

That is a striking result, and an important result, for it tells legal reformers that they do not have to make reputational shifts as dramatic as to those of the Soviet Union, Belarus, or even Mexico, but that even marginal shifts can produce marginal effects. As good a reputation as the U.S. criminal justice systems have now, as compared to some others, they nonetheless can benefit by becoming even more just in the community's view, and can be hurt by becoming less just in the community's view.

\section{Seven Studies that Purport to Undermine Empirical Desert}

In their recently published article in this Law Review, Christopher Slobogin and Lauren Brinkley-Rubinstein (SBR) report seven new studies. In their view, "the studies 
we have reported here tend to undermine all three hypotheses underlying empirical desert theory. ${ }^{174}$ The three hypotheses they claim underlay empirical desert and that they have refuted include: the "consensus hypothesis" - that there exists consensus on the relative ranking of many offenses, based on desert; the "compliance hypothesis" - that deviations from empirical desert undermine moral credibility and thereby reduce compliance and cooperation; and the "crime control hypothesis" - that the crime-control benefits of empirical desert are as great or greater than those of a distributive principle focused on their notion of "individual prevention. ${ }^{75}$ Unfortunately, a look at their studies suggests no such undermining of empirical desert (or support for their "individual prevention").

\section{A. Studies Said to Undermine Empirical Desert by Refuting Its "Consensus Hypothesis"}

In Study 1, which they entitle "Is there consensus about the ordinal ranking of crimes?," SBR offer a variation on the rank-ordering of scenarios done in the Robinson and Kurzban study, Concordance and Conflict in Intuitions of Justice. ${ }^{76}$ Apparently they believe that such consensus is necessary for empirical desert to work as an effective distributive principle. ${ }^{77}$ But, in this, SBR are wrong. Empirical desert requires no such concurrence of agreement. If it did, the Robinson-Kurzban studies would have killed empirical desert on the spot, for they demonstrated both points of concurrence and points of conflict among peoples' judgements about justice. Even if community views on an issue were expressed by a bell curve, rather than (say) a single point, the law's moral credibility could still be improved by moving from a point on the tail of the curve to a point nearer the center, since this would reduce the number of people with whose intuitions the law conflicts and the extent of that conflict.

In their study, Robinson and Kurzban show that, contrary to the common wisdom of the day, which suggested that there was no agreement among people about deserved punishment on any matter,$^{78}$ there do in fact exist some matters on which there is nearly universal agreement across all demographics. This was significant because the common wisdom at the time was that it was hopeless to even consider the significance of lay persons' shared judgements of justice because there was essentially no such thing. Everyone simply has a different view. As Michael Tonry observed: "How do we know how much censure, or 'deserved punishment,' a particular wrongdoer

${ }^{74}$ SBR, supra note 2 , at 119 .

75 Id. at $119-20$.

${ }^{76}$ Paul H. Robinson \& Robert Kurzban, Concordance and Conflict in Intuitions of Justice, 91 MINN. L. REV. 1829 (2007) [hereinafter Concordance and Conflict].

77 See SBR, supra note 2, at 85-86 (suggesting that an "assumption[] underlying empirical desert" is that "there is strong societal consensus about deserved punishment, at least with respect to core crimes such as homicide, assault, and theft"); id. at 119 (suggesting that a "hypothes[i]s underlying empirical desert" is that "consensus exists with respect to the relative ranking of a sizeable subset of crimes"). SBR also argue that "widespread disagreement" over the absolute punishment due in any given case puts empirical desert "in trouble from the start because there is no societally accepted baseline to which the criminal justice system can adhere even if it wants to track lay views on punishment." Id. at 89-90. See also id. at 95-96 (noting that "people vary widely in their assessments about specific punishments" and suggesting that "this could derail empirical desert at an early stage").

${ }^{78}$ Concordance and Conflict, supra note 76, at 1846-48. 
absolutely deserves? God may know, but as countless sentencing exercises have shown, people's intuitions about individual cases vary widely." ${ }^{79}$ But the findings of the Concordance-Conflict study killed that common wisdom. There are some matters twenty-four specific case scenarios in that study - on which there is almost universal agreement as to relative blameworthiness and deserved punishment.

This finding had important implications for the law's approach to lay judgments of justice. The existence of a high level of agreement, as well as the way subjects made their judgements, suggested that such judgements were commonly intuitional rather than reasoned, which meant that they could not be simply undone by offering good reasons for an alternative view. Further, and perhaps more importantly, the high level of agreement on some issues suggested that, if the intuition could withstand the enormous influences of differences in life experience across different demographics, then it could probably withstand the kinds of influences of any reform program seeking to "re-educate" the community out of that view. In essence, widely shared intuitions of justice, having not been shaped by reasoning in the first place, are not likely to be easily changed by it either.

The SBR study used some of the Robinson-Kurzban high-concurrence scenarios and added additional facts to them, such as expressions of remorse or an offender's prior offense. Other studies by Robinson and co-authors have shown that such factors have an effect on people's perception of deserved punishment but not at the high level of agreement commanded by the factors used in the original Robinson-Kurzban. ${ }^{80}$ What results would one expect when such lower-agreement factors are added to scenarios consisting of high-agreement issues?

Presumably, the level of agreement on the rank-ordering of the revised set of scenarios would go down. And it did, although only slightly. ${ }^{81}$ Indeed, we would not have been surprised if it had gone down even more.

It is hard to see how this is inconsistent with any of the claims in the RobinsonKurzban study about the existence of agreement on some matters of deserved punishment. ${ }^{82}$

But SBR want to draw other conclusions from their study, which have nothing to do with the level of agreement titling of the study. They want to use it as a test of whether adding facts that go to preventive concerns - "relative dangerousness or treatability"83 - rather than desert concerns, will reduce the degree of agreement, and/or change the ordinal rankings "in ways inconsistent with desert." ${ }^{84}$ As to the first issue, Robinson and co-authors have never tested whether purely preventive factors might

79 Michael Tonry, Obsolescence and Immanence in Penal Theory and Policy, 105 COLUM. L. REV. 1233, 1263 (2005).

80 See Paul H. Robinson et al., Extralegal Punishment Factors: A Study of Forgiveness, Hardship, Good Deeds, Apology, Remorse, and Other Such Discretionary Factors in Assessing Criminal Punishment, 65 VAND. L. REV. 737, 774 et seq (2012) [hereinafter Punishment Factors].

SBR obtained a 0.836 Kendall coefficient for the control group, which was exposed to the original Robinson-Kurzban scenarios, and a 0.816 coefficient for the experimental group, which was exposed to the modified scenarios. SBR, supra note 2, at 90-93.

82 Indeed, SBR themselves say their "research confirms that consensus about the ranking of core crimes exists." Id. at 119.

83 Id. at 90.

84 Id. at 120. 
reduce agreement. Their work has focused only on agreement as to deserved punishment. The SBR inquiry is an interesting one - it just has nothing to do with prior claims by Robinson and co-authors. The second issue has in fact been discussed by Robinson and co-authors and has been largely resolved by them and others: studies show that preventive concerns do not typically alter ordinal punishment rankings "in ways inconsistent with desert." Instead, people make relative punishment judgements based almost entirely on desert. ${ }^{85}$

85 See, e.g., Kevin M. Carlsmith et al., Why do we Punish? Deterrence and Just Deserts as Motives for Punishment, 83 J. PeRSONALITY \& SOC. PSYCH. 284 (2002); John M. Darley et al., Incapacitation and Just Deserts as Motives for Punishment, 24 LAW \& HUMAN BEHAVIOR 659 (2000); Kevin M. Carlsmith, The Roles of Retribution and Utility in Determining Punishment, 42 J. EXPERIMENTAL SOC. PSYCHOL. 437 (2006); Norman J. Finkel et al., Recidivism, Proportionalism, and Individualized Punishment, 39 AM. BEHAV. ScI. 474 (1996); Kevin M. Carlsmith, On Justifying Punishment: The Discrepancy Between Words and Actions, 21 Soc. JUST. RES. 119 (2008); see generally Kevin M. Carlsmith \& John M. Darley, Psychological Aspects of Retributive Justice, 40 ADV. EXP. SOC. PSYCHOL. 193 (2008) (surveying the literature and discussing the desert-based orientation of lay punishment judgements).

Citing a number of other studies, as well as their own, SBR argue that "when people make decisions about relative punishment they are willing to consider more than desert." SBR, supra note 2, at 92-93 (emphasis added). Certainly there are circumstances in which people are "willing" to deviate from desert. We know that people's intuitive (i.e. default and automatic) punishment judgements are grounded in desert, but we also know they can be overridden by conscious reasoning processes if particularly compelling reasons for deviation are perceived. (Research shows that even these reasoning processes are generally driven by desert considerations, but, of course, sufficiently compelling reasons can produce exceptions. Kevin M. Carlsmith \& John M. Darley, Psychological Aspects of Retributive Justice, 40 ADV. EXP. Soc. PSYCHOL. 193, 211-17 (2008).) People's commitment to desert is strong and intuitive, but this does not mean it is more important to them than anything else in the world - such as protection from a crazy man. If they are forced to choose between desert-based punishment and protection from physical injury or death, they may well be "willing" to choose the latter. But this hardly undermines the claim that people naturally think of punishment in desert terms. Nor does it undermine empirical desert in any way.

More troubling is SBR's later claim - a stronger one - that desert is not "the only or even the principal determinant of society's views on ordinal ranking of [offenses]." SBR, supra note 2 , at 93. This is contrary to the available data and, as we show, nothing in SBR's study supports it. It is not clear that SBR think their earlier cited studies support this stronger claim. See id. at 92 n.67. But, if they do think this, they appear to be mistaken. The first study they cite simply finds that people's perception of offense seriousness is influenced by the amount of resulting harm, the offender's recklessness, and any associated deprivation of person or property. See Jeremy A. Blumenthal, Perceptions of Crime: A Multidimensional Analysis with Implications for Law and Psychology, 38 MCGEORGE L. REV. 629 (2007). Since all of these factors are relevant to desert assessments, how could these findings possibly show that people do not think of punishment in desert terms? If anything, the opposite is true.

The second study SBR cite finds that people sometimes support various aspects of restorative processes in lieu of formal court-imposed imprisonment. See Dena M. Gromet \& John M. Darley, Restoration and Retribution: How Including Retributive Components Affects the Acceptability of Restorative Justice Procedures, 19 SOC. JUST. RES. 395 (2006). But the study's results are entirely consistent with empirical desert and, indeed, exactly as one would predict. Participants in the study were told that, under the restorative programs in question, "the victim and offender may work out an agreement outlining what the offender must do to atone for his 
Unfortunately, SBR provide a poor test of these issues, for they pick as factors to add to the Robinson-Kurzban scenarios many elements that prior research has shown affect people's judgement of deserved punishment. ${ }^{86}$ Thus, the continuing agreement that SBR observed could just as easily be a product of agreement on perceived desert rather than agreement on purely preventive matters. Likewise, the change in ordinal rankings that followed the injection of the extra factors could simply reflect those factors' perceived desert implications. If SBR want to pursue their interest in determining the effect of preventive considerations on relative punishment judgements, what they need to do is to add facts that promote prevention but conflict with empirical desert, as is often the case.

For example, while empirical desert would want to provide a defense or mitigation for mentally ill offenders, a purely preventive approach would want to impose full liability and punishment: Since these dysfunctional offenders are particularly likely to be dangerous, a preventive approach would logically pursue the lengthiest sentence possible in order to minimize the public risk. Similarly, an empirical desert approach would give significance to resulting harm - punishing murder more than attempted murder, punishing aggravated assault resulting in quadriplegia more than an identical attempt that causes no harm. A purely preventive approach, on the other hand, would

\section{5 (...continued)}

wrongs," and that this might include "apology, monetary compensation, some services that the offender does for the victim, community service, and the like." Id. at 426 . Each of the items on this list has some associated punitive "bite," which could easily satisfy the total punitive "bite" required by desert, at least for low-level offenders. (Desert cares nothing about punishment method; only about punishment amount.) This explains why the study's subjects used restorative programs (instead of court-imposed prison) only for minor offenses, rather than for mid-level or serious ones: subjects might doubt whether the available "atonement" measures are punitive enough to satisfy the deserved punishment amount for crimes as serious as rape and attempted murder. It also explains why subjects granted sentence reductions to offenders who successfully completed restorative programs: such offenders have already experienced some punitive bite and prison need only take care of the remaining amount required by desert. And, finally, it explains why offenders who did not successfully complete their programs were assigned prison sentences similar to those who underwent no programs at all: neither offender had experienced any prior punitive bite and both therefore deserve the same sentence.

The third study they cite examines a range of prior studies measuring public support for the death penalty, prison, and non-incarcerative penalties - issues that have no bearing on empirical desert or people's orientation toward desert-based punishment. See Francis T. Cullen et al., Public Opinion About Punishment and Corrections, 27 Crime \& Just. 1 (2000). It also reviews studies measuring public support for rehabilitation and "get tough" laws, though most of these studies were conducted through public polls or other questionnaires that ask subjects to express preferences in the abstract. Such "verbal reports" are notoriously unreliable: subjects who express a view in response to a general question often act inconsistently with that view in practice. Kevin M. Carlsmith \& John M. Darley, Psychological Aspects of Retributive Justice, 40 AdV. EXP. SOC. PsYCHOL. 193, 198 (2008); Kevin M. Carlsmith, On Justifying Punishment: The Discrepancy Between Words and Actions, 21 Soc. JUST. RES. 119 (2008). In the few studies reviewed that utilized crime-specific vignettes, support for "get tough" laws was scant, and support for rehabilitation as a distributive principle rather than a correctional policy - was minimal.

We fail to see how any of these studies undermine empirical desert or the claim that people make relative punishment judgements based largely on desert.

${ }^{86}$ See supra note 80. 
not want to distinguish between the harmful offense and the failed attempt, at least where the failure was a matter of pure luck, as opposed to (say) ineptness or some other factor indicating a lower level of dangerousness.

Prior studies have examined the effect on lay judgements of just these sorts of facts. And they have found that people generally factor them into their punishment assessments in ways consistent with desert, but inconsistent with prevention. ${ }^{87}$ SBR's study does little to challenge these findings. And, given the available data, it is not clear that they could.

Overall, we find little value in Study 1. Indeed, we are puzzled that SBR would even want to conduct it: they announce their goal as testing the validity of empirical desert, but nothing about empirical desert actually depends on the issues they purport to test. As we have shown, nothing in empirical desert requires agreement on the ordinal ranking of offenses (far less agreement based on preventive considerations). Nor does empirical desert require that everyone always think in desert terms in every punishment decision imaginable. The benefits of moral credibility (stigmatization, avoiding vigilantism, promoting support and assistance and avoiding resistance and subversion, influencing norms, gaining deference in borderline cases) would flow from a desert-based system even if people did sometimes factor non-desert considerations into their punishment judgements.

In short, nothing in this study undermines any aspect of empirical desert (or supports any aspect of SBR's "individual prevention" proposal).

In their Study 2, SBR asked their subjects for specific punishment amounts rather than a rank-ordering of scenarios. We know that, even though many people agree on the relative blameworthiness of different cases, they often disagree on the general severity of punishment appropriate for a criminal justice system. Some prefer more harsh punishments generally, some prefer less harsh. When asking subjects for specific sentences for the different scenarios, even if the subjects agreed on the rankordering of the blameworthiness of the cases, what would one expect as to the rankordering of the specific sentences they give? Presumably, their disagreement regarding the general level of severity of punishment would introduce a corresponding measure of disagreement about the specific sentences for the different scenarios. And this is what SBR found.

Again, it seems hard to see how these results are anything but consistent with previous studies and claims with regard to empirical desert. One does not need perfect agreement among the community with regard to specific sentences for specific cases. The point is that one can improve the criminal law's current moral credibility by reducing the extent of its conflicts with community views, including trying to be as consistent as possible in matching community judgements about the relative punishment of different cases. A system that gets the relative ranking of cases correct, even if there remains community disagreement over general severity, will be seen as having greater moral credibility than a system that, suffering the same community disagreement over general severity, also gets the relative ranking of cases wrong. What the empirical desert and moral credibility research suggests is that any marginal improvement in moral credibility can produce a corresponding improvement in crime-control effectiveness.

87 See, e.g., John M. Darley et al., Incapacitation and Just deserts as Motives for Punishment, 24 LAW \& HUMAN BEHAVIOR 659, 671-75 (2000) (finding that people overwhelmingly give a defense or mitigation to mentally ill offenders, even where the relevant illness is associated with greater dangerousness). 
To summarize, SBR erroneously assume that empirical desert requires high agreement among people to produce its crime-control benefits, but in truth it need only provide more moral credibility than currently exists to get a corresponding increase in crime-control benefits. People will always disagree about some empirical desert matters, as Robinson and Kurzban have shown, but law can improve its moral credibility by following the path that will produce the least amount of disillusionment in the smallest number of people, whatever the level of agreement may be. Nothing in this study undermines empirical desert or moral credibility in any way (or supports SBR's "individual prevention" principle in any way).

\section{B. Studies Said to Undermine Empirical Desert by Refuting Its "Compliance Hypothesis"}

In Study 3, SBR sought to test each of their subjects "degree of dissatisfaction with the law," as they called it, with the subjects "noncompliance" with the law. ${ }^{88}$ They took each subject's "degree of dissatisfaction with the law" to be reflected in the extent to which the subject agreed or disagreed with the statutory maximum penalties that that subject thought their jurisdiction set for various offenses. They took their measure of "noncompliance" to be reflected in the subject's answers to questions on Janice Nadler's Likelihood of Criminal Behaviour Questionnaire. Their hypothesis was that there would be no relation between a subject's "degree of dissatisfaction" and her "likelihood of noncompliance." 89

This seems like an interesting study, but it hardly tests the principles and concepts that Robinson and his co-authors have been writing about. First, Robinson's focus is not on the "degree of dissatisfaction with the law" generally, as SBR are trying to test, but rather with a more specific measure: the "moral credibility" of the criminal law in the community's eyes. As we will show, "dissatisfaction with the law" is too crude a target. One may think the criminal justice system does many things very badly - its police are rude and intrusive, its judges are arrogant and remote - yet think that it does a very good job at giving offenders the punishment that their moral blameworthiness deserves, no more and no less. That is, people may be dissatisfied with the criminal justice system in many ways yet have respect for its justness in distributing punishment. For example, as Robinson has discussed elsewhere ${ }^{90}$ a system might get high marks for its procedural fairness - giving rise to what Tom Tyler labels its perceived "legitimacy" - yet get low marks for its "moral credibility" - reliably giving deserved punishment that matches the extent of the offender's moral blameworthiness.

Further, a subject's view on the "moral credibility" of the system can hardly be measured by her view on the state's statutory maximum sentences for various offenses. The research by Robinson and co-authors always involves asking lay subjects their views on specific factual scenarios - short one-paragraph stories - because that is what triggers lay people's judgements of deserved punishment. People appear to construct a story in their heads of the events, which then triggers what in many instances is an intuitional judgement about the relative seriousness of the wrongdoing and the appropriate amount of punishment. Certainly lawyers, judges, law professors, and system designers have more sophisticated notions about how the criminal justice

90 Fairness and Justice, supra note 23. 
system works and what various parts of it - such as its statutory maximums - mean for ultimate case dispositions, but lay persons do not have this level of knowledge, at least in any reliable way. As Robinson and Darley have shown in one of their studies, subjects commonly know nothing about the formal law itself, even though they often think that they do. ${ }^{91}$

Worse for SBR, different subjects are likely to make different assumptions about what the implications are for a legal abstraction like a "statutory maximum" sentence. Thus, asking lay subjects their opinions of various statutory maximums leaves us with little information about what the resulting data actually means. What do subjects have in mind when they imagine the offenses at issues? Every subject could be imagining a different story. Different subjects could have different views of what effect a statutory maximum has on the actual punishment imposed in most cases, or even any case. (In fact, the vast majority of statutory maximum punishments have no effect in the vast majority of cases because sentences are typically far below the maximum.${ }^{92}$ ) The subjects in the SBR study might (or might not) guess that a "statutory maximum" does not dictate a sentence but rather sets a maximum below which a judge can chose to impose something quite different. Could a subject's view on the propriety of various statutory maximums bear some correlation to the "moral credibility" the system has with the subject? One might guess that there could be some diluted relation, although it is likely to be a weak one.

SBR's other measure fairs no better at testing the concepts and principles offered by Robinson and co-authors. SBR compare the subjects' degree of dissatisfaction with the statutory maximums with the results of Nadler's scale, which SBR take as their measure of "noncompliance" with the law. We have no experience with Nadler's scale, so we have no sense of whether it is a good measure of noncompliance or not. Our objection is that our claim about the effects of a system's moral credibility involves much more than the compliance or noncompliance of the subject at hand.

Look back to the five mechanisms by which we have suggested moral credibility has its influence on the system's "crime-control effectiveness": those mechanisms include much more than just getting a person to not break the law themselves (which seems to be SBR's narrow focus, for reasons unclear). For example, the first mechanism - deviating from a community's principles of justice can inspire resistance and subversion among participants (witnesses, juries, judges, prosecutors, and offenders) where effective criminal justice depends upon acquiescence and cooperation - has nothing to do with dissuading the potential offender but rather with the effect of the system's moral credibly on the legions of people upon which the system depends to operate effectively. SBR's narrow focus on the potential offender suggests a lack of

91 John M. Darley, Kevin Carlsmith, \& Paul H. Robinson, The Ex Ante Function of the Criminal Law, 35 LAW \& SOC'Y REV. 165 (2001) (finding that people know little about the criminal code of their state and, instead, simply assume it to be as they think it should be).

92 See Jamison v. Klem, 544 F.3d 266, 277, 277 n.9 (3rd Cir. 2008) (noting that the "theoretical maximum" is "rarely imposed," and that "the authorized maximum frequently bears no relationship to the sentence that is imposed."). Indeed, the imposition of a statutory maximum sentence is rare enough that some prosecutors have never even heard of it happening. See also id. at 277(noting that the prosecutor "knew of no instance of a maximum sentence being imposed during her four years as a prosecutor."). 
appreciation for what makes for effective crime-control - just the kind of narrow thinking that the empirical desert-moral credibility writings seek to avoid.

The third and fifth mechanisms - stigmatizing violators and creating power in the criminal law to help shape community norms - are similar. They operate not by dissuading law-breaking by the potential offender directly but rather by creating in the community, including the potential offender's friends, family, and acquaintances, the substantial influence of social stigmatization, and by creating in the criminal law the potentially enormous power to shape norms and to cause them to be internalized. In fact, it is only the fourth mechanism - the effect of moral credibility to get a potential offender to defer to the law in morally ambiguous areas - that seems to be tested by SBR's measure. Thus, again, while SBR's measure of "noncompliance" is an element of the system' overall "crime-control effectiveness," it is only a part of it.

What is striking about SBR's study results is that, despite the fact that both measures being compared only roughly track empirical desert's notion of moral credibility (not general "dissatisfaction with the system") and effective crime-control (not "noncompliance"), the study still finds that "dissatisfaction" with statutory maximums does in fact predict "noncompliance"! Under the conditions of these studies, we would not have been surprised if there was no effect found, yet there was one. That SBR characterize the effect as "weak"93 is both a matter of opinion and beside the point. Even despite the muddled measurers used here, the study showed a moral credibility effect. With this study SBR have not undermined empirical desert but rather confirmed it, giving it empirical support that it did not previously have.

What strikes us as near bizarre, is SBR's conclusion that "Study 3 suggests that, while failing to adhere to desert might cause some noncompliance, failing to adhere to utilitarian goals could cause even more noncompliance." ${ }^{14}$ Study 3 did not even attempt to test a difference in effect between desert and preventive (or "utilitarian"95) factors. It sought to test the relationship between "dissatisfaction" and "compliance" without distinguishing the desert or preventive basis for the "dissatisfaction." How could it even start to generate a conclusion on the former issue?

In their Study 4A, SBR gave some subjects the same six scenarios they used in Studies 1 and 2, concerning extent of agreement, and told them the offender received what SBR call "a reasonably 'just' sentence based on our data." ${ }^{96}$ To other subjects they gave the same scenarios but told them the offender received a sentence that SBR set as being different from what they thought the subjects would see as just. (Among subjects receiving the unjust sentences, SBR gave some people the regular scenarios, and other people the scenarios modified by what they called "utilitarian factors" - by which they mean "preventive factors" - but which earlier studies have shown,

93 SBR, supra note 2, at 102.

94 Id. at 103.

95 SBR often use the term "utilitarian" when they mean to refer to preventive factors, such as dangerousness, but this is confusing terminology: Empirical desert is itself a utilitarian mechanism, which seeks to control crime by influencing the conduct decisions of the community (through the five mechanisms described in Part I). For examples of this sort of conflation, see id. at 79, 81, 82, 87, 90, 93, 101, 112, 119, 120, 121, 124 (2013).

96 Id. at 104. 
unfortunately for SBR, to have empirical desert implications ${ }^{97}$ ) They then tested all of the groups to see if they showed a difference in "noncompliance."

What should we expect here? Is there some reason to think that, because a subject reads six scenarios and is told that the "offender" in each got an unjust sentence, this experience would so unsettle her as to make her change her view of her own criminal justice system and thus change her view as to her willingness to assist, defer, comply with it, or to take it as a reliable teacher of what is truly condemnable, and so on? It seems unlikely that such a bland experience would change her views on the criminal justice system under which she has lived for many years. She comes to the lab with a developed view of the moral credibility of the system - a view formed no doubt by having heard about any number of cases with whose results she (dis)agreed. Why would reading the six scenarios here change her view? As we discussed in Part I, it takes some doing for researchers to create in an hour in a lab even a nudge to the system's moral credibility.

In the Disutility of Desert studies, for example, the researchers had to work hard to produce that nudge in moral credibility. They used specific real-world cases that produced dramatically unjust results - cases that would have (and did) create newspaper headlines. For whatever reason, SBR chose not to use the method shown to be effective in Disutility, but instead made up their own approach, using bland cases that read like the hypotheticals that they were and that reported sentences that were not what the subject wanted but were hardly headline material.

It is no surprise to us to find that the subjects' reading of the six cases had no effect on their noncompliance. And, apparently, neither was it to SBR. Concluding that the sentences they used "were not sufficiently aberrant to occasion any response,"98 they "altered [their] methodology to conform more closely to the methodology followed in The Disutility of Injustice." ${ }^{19}$ But then, in Study 4B, they proceeded to use the same scenarios and sentences; their only change was to ask their test questions in a different order. Again, no effect. "[N]one of the groups differed significantly on the Moral Credibility Scale." ${ }^{100}$ Having failed to produce a change in moral credibility, they had no stimulus whose effect they could test for a change in noncompliance.

Why would they have not simply used the proven Disutility scenarios to produce the needed change in moral credibility, rather than letting their entire experiment fail? Perhaps because many if not most of the Disutility scenarios that produced the needed outrage were based on the coercive crime-control doctrines that SBR are trying to promote. Perhaps they concluded that it would not be good advertising for their proposal to highlight how prevention-based doctrines, like those used in the Disutility

97 Because SBR's approach could not produce any effect in any group, they were unable to test their theory about the regular and the regular-plus-preventive scenarios. Of course, even if they had not had the experimental failure, they would not have been testing the desert-preventive distinction that they had hoped, for the reasons we discussed previously, at supra pp. 19-22. Their supposed "utilitarian factors" commonly were nothing of the sort, but often had significant desert implications, such as prior criminal record or remorse. To test pure preventive factors, without desert implications, they would have to look to such factors as mental illness or resulting harm, where desert and pure prevention suggest clearly different results.

98 SBR, supra note 2 , at 105.

99 Id.

100 Id. at 106. 
study, would so clearly carry significant crime-control costs - exactly the opposite of what SBR want to claim for their "individual prevention" principle.

It is hard to know what conclusion to draw from Studies $4 \mathrm{~A}$ and $4 \mathrm{~B}$, other than to suggest how little SBR seem to understand their subjects and how they think, and to wonder why SBR would not use the nudge techniques shown to be effective in Disutility if they really wanted to test their theory. In any case, nothing in either of these studies undermines empirical desert or moral credibility in any way (nor supports their claims regarding "individual prevention" in any way).

In Study 5, SBR had a group of their law students read Nadler's stories about legislation that would deprive individuals of property, income, or privacy. They then had another group of their law students read Nadler's story about a person not prosecuted for conduct that most students probably thought was blameworthy. A control group read no story. SBR then tested half of each group right away, getting an uptick in Nadler's noncompliance scale, and tested the other half of each group after a delay of seven to ten days. With the delay groups, they got no uptick.

We find it a pleasant surprise that they got an uptick even with the immediate test group. How trivial an adjustment in a person's view of the moral credibility of their criminal justice system is one likely to get from reading a story about a single case in which a person did not get the minor punishment they deserved? Or how trivial the effect of reading a story about unjust legislation - with no indication that any actual injustice was done to anyone as a result of it? That they got any uptick at all under such circumstances suggests a surprising degree of sensitivity of the influences involved.

That their observed effect was lost when the students were not tested for seven or ten days is actually as one would predict. Given the lives of law students and what they get exposed to every day (which is why careful researchers do not use law students for such studies if they can help it), would the law students even remember what they had read a week before? Even if the student did remember the scenario, it would surely have lost its salience by the following week, fading behind both the accumulated experience of their previous life experience and the various cases and materials studied in law school over the past week. No meaningful conclusion can be drawn from this result, especially as it contradicts none of the claims of empirical desert proponents.

Even if the cases and materials that the students had been exposed to were not Nadler's mild stories but the real and outrageous cases used in Disutility (in which coercive crime-control doctrines based on preventive rationales really did produce gross injustices), one would expect that the effects of this exposure would fade over time. As noted above, subjects come to the lab with well-developed views of criminal justice from many years of observation of the system. When they leave the lab, of course their views fade to the pre-lab baseline, because they fall immediately back into the same old messages about the criminal justice system that created their baseline views in the first place. If they stepped out of the lab and flew to Belarus or Mexico to live, retesting would likely show results based upon their experience there, which is likely to be different from their U.S. baseline.

Indeed, the reform agenda of empirical desert and moral credibility is counting on the fact that the effect of earlier injustices and failures of justice will fade with time. If they did not, what would be the point of trying to make the system more just? If peoples' view of the law's moral credibility will not change with a changing environment, then it is hopeless for reformers to try to improve the system's moral credibility once it 
has earned a bad reputation. But if the system's existing reputation can be changed, then there is a path to greater moral credibility and its benefits.

Again, nothing in this study undermines any aspect of empirical desert or moral credibility (or supports SBR's "individual prevention" proposal).

\section{Studies Said to Undermine Empirical Desert by Refuting Its "Crime Control Hypothesis"}

In Study 6, SBR gave one group of subjects information about four repeat offenders and a second group the same information plus additional information about treatment programs that could help each kind of offender. They then asked the two groups to sentence each of the four and to specify the amount of that sentence of imprisonment that could be spent in the community, presumably at the treatment program. SBR found that the second group on average provided lesser sentences and allowed more of the sentence to be served in the community.

The fact that the subjects were more willing to let the sentence be served in the community after being told of effective treatment programs there is obviously as one would expect. Even a subject focused strictly on desert presumably would want the deserved punishment to be imposed in a way that maximized rehabilitation. Caring about justice hardly makes one opposed to rehabilitation. As Robinson argues in Distributive Principles, ${ }^{101}$ rehabilitation makes an excellent correctional policy. We ought to do it whenever it can work. It is not a good substitute for giving people the punishment they deserve, but it need not be. Offenders can get the punishment they deserve, and also get rehabilitation, with punishment credit given for the punitive bite inherent in any rehabilitation program in which they participate.

The more interesting results in this study are those that show lower overall sentences when subjects were told of effective rehabilitation programs than when they were not told of them. These results do not surprise us, and they do not show what SBR think they show. The group told of the successful treatment programs are more likely to assess an offender as less deserving of punishment because they are more likely to see the offender's offense as at least in some part a product of a disease or a mental or emotional dysfunction or whatever else the subject is being successfully treated for. That is, if the offense is something for which the offender can successfully be treated, as they have been told, then the subjects are less likely to see the offense as strictly the product of the offender's selfishness, greed, or indifference (to others' interests or the law's demands). The more they see the treatment program as capable of "fixing" the offender, the more they will see the offender's fixable flaw as responsible for the offense rather than his selfishness, greed, or indifference. ${ }^{102}$

101 DISTRIBUTIVE PRINCIPLES, supra note 1, at 108, 226-27.

102 This shows one way in which average sentences might decline over time in a way compatible with empirical desert. Insofar as successful treatment programs are developed, and people come to see the success of these programs as indicating lower levels of blameworthiness in those who benefit from them, society will have less inclination to impose punishment in such cases. This is a potentially fruitful avenue for reform that is completely compatible with empirical desert. A recent study using cognitive-behavior therapy to combat youth violence in Chicago is a fine example of the sort of work we would commend, and find to be compatible with empirical desert. See Sara Heller et al., Preventing Youth Violence and Dropout: A Randomized Field Experiment (National Bureau of Economic Research, NBER 
This dynamic fully explains the sentences given as being strictly the product of the subjects' classic desert assessments based upon the offender's moral blameworthiness - not, as SBR appear to want to claim, some natural inclination of the subjects to want to deviate from desert in favor of prevention.

But assume for the sake of argument that you had never heard the explanation offered above for the lesser sentences by the group who were told of successful rehabilitation programs. What then would one make of the results? Would they suggest that subjects were willing to violate desert in order to promote prevention, as SBR want to claim? Clearly no. SBR's reduced-sentence-to-promote-prevention explanation simply does not work. If that were the subjects' view, they would have given a sentence equal to the term of the treatment program. In fact, in each case, the subjects gave a sentence that was more than was required for the rehabilitation program. What SBR have shown is just the opposite of what they want to claim. Even though the preventive needs could have been satisfied with the treatment term, the subjects insisted on giving more punishment than that in order to fulfill the empirical desert requirements.

Perhaps for these reasons, SBR analyze their Study 6 with a bit of double-talk. Instead of claiming that the subjects deviated from desert to promote prevention, which they cannot say, they say instead: "people's views of desert are affected by preventive considerations." ${ }^{103}$ What could this possibly mean? It makes little sense. How could a person's assessment of desert (moral blameworthiness for a past offense) be affected by preventive considerations (the measures required to prevent a future offense)? ${ }^{104}$

It is true that some liability and punishment rules produce results that are consistent with both desert and prevention. For example, both principles would seem to support a rule that would have punishment increase as the seriousness of the harm intended by an offender increased. Trying to cause death is more blameworthy and, all other things being equal, probably suggests greater dangerousness, than just trying to cause property damage. If SBR are pointing out that desert and prevention do not always in every instance conflict, then they are simply stating the obvious.

It is as often the case that desert and prevention do conflict, however, and this is why there are debates about the alternative distributive principles for criminal liability and punishment. As noted above, ${ }^{105}$ for example, all other things being equal, trying to cause death or cause quadriplegia and actually causing a death or actually causing

\footnotetext{
102 (...continued)

Working paper No. 19014, 2013), available at http://www.nber.org/papers/w19014.

103 SBR, supra note 2, at 114; id. at 112 (entitling Study 6 as: "To what extent are assessments of desert affected by preventive considerations?").

104 It is worth noting that, as with scenarios in previous studies, the scenarios SBR use in Studies 6 and 7 are not free from desert implications, making them again, at best, highly impure tests for their purposes. This is so in two ways. First, undergoing non-voluntary treatment programs, all of which involve supervision by authorities, is rightly seen by many people as a sort of punishment, not merely an alternative to it. So, we cannot be clear that the participants do not think they are giving the person in the scenario what they deserve. Second, those who fail to complete the program might be seen as being engaged in "defiant" behavior, and on at least some accounts, this is a core element in negative desert. See Jean Hampton, The Nature of Immorality, 7 SOC. PHILOSOPHY \& POL. 22, 39-40 (1989). That these scenarios are not "clean" of desert elements gives us one more reason to doubt the conclusions that SBR draw from them.

105 See supra pp. 21-22.
} 
quadriplegia may show identical dangerousness (if the failure is a matter of pure luck), but will suggest dramatically different degrees of moral blameworthiness to lay persons. Similarly, being mentally ill may suggest increased dangerousness but it also suggests reduced blameworthiness. What SBR need to show is that lay people are happy to ignore blameworthiness in such cases of conflict in order to promote prevention, which they have not done.

Just to be clear, we do not doubt that people can be drawn into giving punishment that violates desert in order to promote preventive detention. People want to protect themselves and others from victimization. Safety is important. If other societal institutions fail to protect the community, any institution, including the criminal justice system, may be seized upon to do the job.

But just because people can be forced to preventive measures that do injustice in order to protect themselves, it does not follow that, after doing so, they will have the same respect for the criminal justice system as a moral authority on which they can depend. On the contrary, they will know first hand that the system is now in a quite different business than doing justice. They do not take the current civil commitment system - for persons suffering mental illness or contagious diseases - to be a moral authority, nor are they likely to be tricked into thinking that preventive detention in the guise of criminal justice is a moral authority.

We might prevent some avoidable crimes by transforming the criminal justice system into a system of preventive detention, but to do so would come with a substantial cost. It would sacrifice the crime-control power of the system through all of the mechanisms of social and normative influence discussed in Part I. And, as Robinson has detailed elsewhere ${ }^{106}$ there is no need to make this sacrifice when the goal of preventive detention can be achieved - in a way more fair to detainees and more effective for the protection of the community - simply by doing whatever preventive detention is demanded through a system apart from the criminal justice system (or at least segregated and labeled separately, even if relying upon its commitment authority), so that the criminal justice system can maintain its moral credibility and the social and normative influence that derives from it. ${ }^{107}$

Note that nothing in Study 6 undermines any aspect of empirical desert or moral credibility (or supports SBR's proposed "individual prevention" principle).

In Study 7A, SBR gave subjects six scenarios. Some subjects got scenarios just about an offense. The rest got scenarios with information about both the offense and the various rehabilitation programs that had worked for other offenders, like the programs referred to in Study 6, in which the offender would now be required to participate. In this study, however, the subjects were not asked for a sentence but rather asked which of two sentencing options they preferred: one option was a narrow range of sentences centered on the average sentence given by subjects in previous

106 Paul H. Robinson, Punishing Dangerousness: Cloaking Preventive Detention as Criminal Justice, 114 HARV. L. REV. 1429, 134 et seq (2001) [hereinafter Punishing Dangerousness].

107 As Robinson demonstrates in Punishing Dangerousness, a segregated system of preventive detention would be fairer to detainees and more effective at community protection than a preventive detention system disguised as criminal justice. Id. 
research; the other was a very broad range of sentences, the offender's ultimate sentence within the range depending upon whether he "responds to treatment." ${ }^{108}$

What results would one expect here? It is hard to know because the results depend upon many factors that a researcher cannot know. What would lay subjects make of narrow ranges versus broad ranges? As discussed above, this option has clear implications for criminal law theorists and designers, but may mean little or nothing to lay subjects. Or different subjects may read in different implications that they think might follow from one structural approach or another. These researchers never performed "manipulation checks" on their subjects (in this study or in any of their other studies, apparently) to determine what implications subjects might give one structural feature or the other.

Without data, one might guess that the two structural options themselves had no meaning to subjects other than the extent to which they would allow or prevent the subject from giving the specific sentence that she thought appropriate. Thus, the narrow ranges would seem unattractive to subjects if the range excluded the sentence that the subject thought appropriate for the case. On the other hand, if a subject's sentence was the average sentence for the case or something close to it, then the subject might prefer the narrow range because it would reduce the chance that a judge could give something too far away from what they thought was deserved. Thus, the percentage of subjects preferring the narrow range over the broad might depend on the extent of the spread among subjects in their preferred punishment for the case and the number of subjects who fell within the narrow range around the average.

But somewhat complicating things here is that the two choices given to the subjects differed not only in narrow versus broad ranges but in another respect: the broad range option was one in which the ultimate sentence would depend in part upon "how well [the offender] responds to treatment." ${ }^{109}$ As noted previously, how the offender responds to treatment might have an effect on how a subject assesses his blameworthiness for the offense: the greater the effect of the treatment in altering his likelihood of committing another offense, the less he might be seen as accountable for his own conduct in committing the offense. For subjects making this assumption, the possibility of a later sentence reduction might seem perfectly fine. To others, however, it would not.

Given all of these unknowns about what the choice by subjects between the two options actually means, it is hard to even guess how it might come out. Nor is it possible to draw conclusions from the results, whatever they might be. Without knowing what choices different subjects think they are facing, one cannot know what to make of their choices. It is perhaps no surprise, then, that SBR got no statistically significant results from Study $7 \mathrm{~A}$.

SBR acknowledge part of the design problem described above, noting their concern that the popularity of the indeterminate choice could simply mean that many people preferred a sentence outside of the narrow range. ${ }^{110}$ In an effort to reduce this dynamic, they revised the test materials, in Study 7B, to slightly broaden the sentencing ranges given in both options: a slightly broader narrow range and a slightly broader

108 SBR, supra note 2, at app. C Studies 7A and 7B.

109 Id.

110 Id. at 116 ("[W]e were concerned that the popularity of the indeterminate choice could merely mean that many people in the desert group preferred a desert-based sentence outside the determinate range we gave them."). 
broad range (for example, for the theft and burglary scenario, the narrow range, which had been 6 to 7 years, was broadened to 6 to 9 , and the broad range, which had been 1 to 7 years, was broadened to 1 to 10). It seems unlikely, however that this minor adjustment will solve the large design problem. Subjects will still find the narrow range unattractive if it does not allow what they think is the appropriate sentence. And, of course, with just this change we still do not know what different subjects may be assuming about the meaning and implications of the two structural options they are being presented with. SBR seem to concede that the change did not fix the design problem. Again, apparently, there were no statistically significant results. ${ }^{111}$

Once more, note that nothing in either of these studies undermines in any way any aspect of empirical desert and moral credibility (or supports SBR's proposed "individual prevention").

In a third and final attempt, SBR, in Study 7C, take a different approach. Using twenty-three professional staff at the Law School and forty-six people "off the street," they give each subject six scenarios, without treatment information, and get a sentence from the subject. Then they tell the subject whether the treatment was successful (in four of the cases) or unsuccessful (in two of the cases). Finally, SBR ask the subject if, in the four successful treatment cases, the subject wants to let the person out before completing the sentence the subject had previously imposed, and, in the two unsuccessful treatment cases, if the subject wants to keep the offender past the end of the previously imposed sentence until the experts say he is no longer a threat. ${ }^{112}$

Of the four successful treatment cases, the subjects are most likely to let the offender out early in the three cases in which the success of the treatment might well lead a subject to reconsider their original blameworthiness assessment of the offender and the reasons for his offense - they were told, for example, that the treatment had rehabilitated a juvenile, reformed the mayor, and cleaned-up an addict. The murderer fares less well perhaps because his offense is so serious: to commit such a gruesome offense, there are fewer plausible claims that it was not really the offender's true self at work in committing the offense. One's drug addiction might explain away a theft but what could explain away a kidnap-murder? That is, by using scenarios where the socalled "preventive" factors also have desert content, SBR have left themselves in no position to make claims about how subjects resolve conflicts between desert and prevention. Certainly, they are in no position to claim, as they try to do, that the reduction in sentences reflects a triumph of prevention over desert.

It is also worth noting that the methodology on display here is not something good researchers would use. Recall the design: subjects are given a scenario and asked to give a sentence; they are then given more information and asked if they want to change their original sentence. This is a classic invitation to "demand effect" bias. ${ }^{113}$ It is well documented that, put in such situations, subjects commonly will change their view because they see the experimenters as expecting that they will (or why would they

111 We assume SBR would have told the reader if there had been any statistically significance differences between their two test groups. They did not. Id. at 117 .

112 Id. at app. C Study 7C.

113 For a discussion of demand characteristics and their potential to distort experimental results, see Martin T. Orne, On the Social Psychology of the Psychological Experiment: With Particular Reference to Demand Characteristics and their Implications, 17 AM. PSYCHOL. 776 (1962). 
be running such a test?). ${ }^{114}$ (This is an especially poor design when using law school staff as subjects, because, as the staff here know the experimenters, they are especially likely to be subject to a particular kind of demand effect, the "good subject" effect. ${ }^{115}$ ) A common way of dealing with the problem is to use a two-group methodology, where one group gets the treatment-results information and the other does not, allowing the experimenters to then compare the two groups' responses. SBR, however, made no use of this standard technique.

SBR have shown, however, assuming the results are not the product of a demand effect, which is possible, that their subjects in the last two cases in Study 7C were willing to continue to detain for prevention purposes beyond the deserved sentence. (These are the two cases in which the treatment did not work and the offenders are shown to be dangerous at the end of their sentence and likely to reoffend. A substantial number of subjects wanted these offenders to be detained further until the experts said they were no longer dangerous. The subjects wanted the offenders to be kept beyond their deserved sentences.)

In other words, SBR's subjects seemed willing to support a preventive detention system. Robinson has elsewhere proposed just such a system - assessing an offender's dangerousness at the conclusion of the deserved punishment within the criminal justice system, and preventively detaining him under a separate civil commitment system if certain conditions are satisfied - and, as noted above, has shown how it would actually be more fair to detainees and more effective for public safety than using the criminal justice system for such a purpose.$^{116}$ Of course, a society can get this sort of preventive detention without having to do injustice to get it - it need not undercut the criminal law's moral credibility - if it will simply be honest about what it is doing, that it is doing it as part of a civil preventive detention system, no longer claiming it is doing criminal justice.

But the important point here is that, as we have said before, if people are induced into promoting prevention in a criminal justice system at the expense of desert, then the system can lose its moral credibility, and thereby its social and normative influence. Perhaps many of SBR's subjects would like having a civil commitment system that detains people for as long as they are dangerous, but these people are hardly likely to look to such a system as a moral authority to use as a guide on what to internalize as truly morally condemnable, or give it any of the other deference that produces the normative crime-control benefits described in Part I.

If their Study $7 \mathrm{C}$ did not have its serious design flaws, it might be taken to suggest that people would not be opposed to a having preventive detention system that detained dangerous people, but in its current form Study $7 \mathrm{C}$ certainly says nothing about whether subjects would be willing to substitute preventive detention for a criminal justice system (or willing to accept the crime-control costs of doing so).

114 See id. at 779 ("[l]f a test is given twice with some intervening treatment, even the dullest college student is aware that some change is expected, particularly if the test is in some obvious way related to the treatment.").

115 Austin Lee Nichols \& Jon K. Maner, The Good-Subject Effect: Investigating Participant Demand Characteristics, 135 J. GEN. PSYCHOL. 151 (2008) (finding that subjects who hold a favorable view of the experimenter are more likely to confirm the (perceived) hypothesis of the study).

116 See supra notes 106-107 and accompanying text. 
It seems hard to see how anything in Study $7 \mathrm{C}$ undermines empirical desert or moral credibility (or supports SBR's proposed "individual prevention" principle).

\section{Conclusions, Implications \& Proposals from the Seven Studies}

What conclusions can one draw from the SBR studies about empirical desert and moral credibility, and about SBR's proposed "individual prevention" principle? In this section we step back to consider the larger debate over the best distributive principle for criminal liability and punishment and how these studies contribute to it.

\section{A. SBR's Erroneous View of the Current Punishment Theory Debates}

As a starting matter, SBR take a somewhat odd view of the current punishment theory debates. They introduce their article by recounting the classic, long-running debate between the desert deontologists and the crime-control utilitarians and note, correctly, that the old debate has taken a new form. We agree: the introduction of the notion of empirical desert and its utilitarian crime-control value in building moral credibility suggests that there are good utility reasons for adopting desert as the distributive principle (at least the empirical desert form of it).

But SBR then describe the "new debate" this way: "both sides are willing to abandon the deontological view of desert."117 In their view, the two asides agree that utilitarian crime-control prevails and the only remaining issue is whether this is best obtained by a focus on pure desert - which is what SBR claim Robinson and his coauthors to want - or best obtained by a prevention-based regime that is sensitive to desert only when ignoring it would create "real de-legitimization of the government and its laws" - which is what SBR want. ${ }^{118}$

This state of affairs will come as a great shock to the large number of moral philosophers and criminal law theorists who remain devoted to deontological desert. ${ }^{119}$ Indeed, their view might even remain the majority view at the moment. Note that the new American Law Institute provision on the general purposes of sentencing, discussed in Part I, adopts desert as its dominant principle and provides that it can never be violated, no matter how great the crime-control payoff. ${ }^{120}$ It does not specify whether it refers to deontological desert or empirical desert. Probably different people had different forms of desert in mind, and some people may have had both forms, but clearly many continue to see deontological desert as still in the game if not its master. ${ }^{121}$

117 SBR, supra note 2, at 78-79 (2013).

118 Id. at 124.

119 Scholars like Michael Moore, Larry Alexander, Kim Ferzan, Leo Zaibert, Jeffrie Murphy, Jean Hampton, Christopher Bennett, Mark D. White, Mary Sigler, Youngjae Lee, Marc DeGirolami, Stephen Morse, Adam Kolber, Antony Duff, and Doug Husak, to name just a few, use deontological desert arguments and would be amazed to hear that it is no longer a serious contender.

120 See supra note 44 and accompanying text.

121 Some participants in the Model Penal Code sentencing project probably did have their eye on the instrumentalist benefits of desert. For example, Michael Marcus acknowledged that desert can serve a variety of social goals: "to prevent vigilantism or private retribution, to maintain respect for legitimate authority, or to enhance respect for the persons, property, or rights of others." Michael Marcus, Motion \#1: Limit Retribution to Occasions of Demonstrable 
The classic deontological-utilitarian punishment theory debate has not been resolved by empirical desert, only made more interesting: it offers a way to partially appeal to the still influential deontologists, by pointing to the significant overlap in results between deontological desert and empirical desert, and a way to partially appeal to the utilitarians by showing that following desert (of the empirical desert type) has important crime-control benefits.

Not only do SBR have the larger debate wrong, they also have wrong the position of Robinson and his co-authors within that debate. SBR represent Robinson as insisting on pure desert (of the empirical desert type), while SBR want prevention without regard to desert unless such would have dramatic crimogenic effect. ${ }^{122}$ We can only assume that SBR have not read Robinson's Distributive Principles book, although they cite it. In its concluding chapter, in which Robinson sets out in five numbered paragraphs the text of his proposed distributive principle, Paragraph 3 provides for deviating from empirical desert when "the crime-control benefits from the deviation outweigh the crime-control costs." ${ }^{123} \mathrm{He}$ is careful to warn that this may be a rare case given the potentially high costs of deviation, but it is a necessary part of the distributive principle for a crime-control utilitarian.

The real point of contention in current debate is whether a distributive principle of empirical desert would have crime-control benefits and whether deviation from it has crime-control costs. Here is where SBR seem particularly confused and selfcontradictory. On the one hand, they challenge the claimed effect of deviating from empirical desert. In their view, their studies "call into question" the "Compliance

121 (...continued)

Need and Effect 2 n.2, AMERICAN LAW INSTITUTE (2007), available at http://www.ali.org/doc/MPC\%20Motion-Marcus-April\%2024-Limit\%20Retribution.pdf. Indeed, for Marcus, these social benefits "cover all that we actually have in mind when we talk about 'just deserts."' Discussion of Model Penal Code: Sentencing, in 2007 A.L.I. PROCEEDINGs 264 (May 14-16, 2007). Professor Richard S. Frase likewise agreed that desert serves social goals, though he would add "fairness to other offenders" to Marcus' list. Id. On the other hand, other participants clearly supported desert at least in part for its deontological value. Professor Kevin R. Reitz, for example, the Reporter for the project, suggested that "there are some sentences that are demanded apart from utilitarian concerns." Id. Mindful of "moral, deontological concerns," he argues that "in some cases of serious crime, it is simply just to respond with a serious penalty." Id.

122 See, e.g., SBR, supra note 2, at 124.

123 DISTRIBUTIVE PRINCIPLES, supra note 1 , at 248. 
Hypothesis," as they call it. ${ }^{124}$ Indeed, at one point, they seem to imply that desertdeviations are literally costless. ${ }^{125}$

Yet in other places their own presentations and discussions concede on their face that there is a crime-control benefit from tracking desert. For example, they describe their proposal as "a sort of limiting retributivism." ${ }^{126}$ If tracking desert has no crime-control benefit and deviating from it has no cost, why would they, as good crimecontrol utilitarians, ever allow desert to divert them from their purely preventive measures? Despite their claim that their studies "call into question" the "Compliance Hypothesis," in fact they concede, repeatedly, that deviation from empirical desert can have crime-control costs. For example, they explain that their prevention-based proposal would be "sensitive to desert only when ignoring it would have crimogenic impact." ${ }^{127}$ They speak in these terms throughout their piece. ${ }^{128}$

But if they concede that deviation from desert has a crime-control cost, why would they even try to refute the "Compliance Hypothesis"? Presumably, what they really want is not to deny the crime-control costs of deviation from desert, but to trivialize them.

124 SBR, supra note 2, at 80 ("[Our] studies call into question the compliance hypothesis, because they find little evidence that divergence from societal views about punishment-whether desert- or utilitarian-based-significantly increases willingness to break the law or diminishes respect for it, especially once the passage of time makes the divergence less salient."). See also id. at 79 ("This Article's investigation suggests that empirical desert exaggerates desert's utility as a crime prevention mechanism while unduly minimizing the efficacy of preventive justice."); id. at 119 ("[T]he studies we have reported here tend to undermine all three hypotheses underlying empirical desert theory."); id. at 121 ("[O]ur research suggests that, if crime prevention is the objective, adherence to empirically derived desert is not likely to be the best way of achieving it. Even the less concrete goal of bolstering the moral credibility of the criminal justice system might be better pursued by following a mixture of desert and utilitarian goals."); id. at 123 ("There may be good reasons to base criminal sentences on assessments of societal views about deserved punishment. But the research reported in this Article suggests that optimizing crime control is not one of them.").

125 "[W]ill a regime based on desert be better at crime control than a regime more directly attuned to prevention? Assuming correctional programs have any efficacy at reducing crime, the answer to this question is unlikely to be yes." Id. at 110 (emphasis added).

126 Id. at 122.

127 Id. at 79.

128 See id. at 80-81 ("Punishment focused on prevention is unlikely to cause major dissatisfaction with the justice system, or more noncompliance with the law, than it preempts through incapacitation, rehabilitation, and [specific] deterrence, unless it represents a radical departure from desert . . . The optimal sentencing system from a crime control standpoint is likely to be one focused explicitly on prevention goals, so long as doing so is not so antithetical to desert that it creates a real possibility of social disruption.") (emphases added); id. at 112 ("Rather than using desert as the linchpin of punishment and hoping that crime prevention will thereby occur, it would make more sense to prefer [preventive dispositions], unless they are so antithetical to desert that vigilantism or other negative effects will result.") (emphasis added); id. at 124 ("[l]f crime control is the objective, the criminal justice system might well be better off pursuing utilitarian goals directly rather than relying on desert as its linchpin. Empirical desert would still be relevant to fashioning punishment, but only to the extent it helps set the boundaries beyond which real de-legitimization of the government and its laws occurs.") (emphasis added). 
The problem with this is that their challenges to the "Compliance Hypothesis," in Studies 3, 4A, 4B, and 5, all fail miserably. They commonly refer to the "unclear preventive payoff associated with empirical desert," ${ }^{129}$ but nothing in their studies supports any such conclusion, as our analysis in Part II.B shows. Indeed, the only thing their studies do is provide new data to confirm the crime-control costs of deviation. ${ }^{130}$

SBR are left then with having to attack empirical desert despite conceding its crime-control benefits and to promote their "individual prevention" principle despite its admitted crime-control costs. The next section, Section B, considers what other claims against empirical desert SBR make, and Section C critiques SBR's alternative distributive principle - "individual prevention."

\section{B. SBR's Alternative Points of Criticism of Empirical Desert: "Unusually Harsh Sentences" and "Expensive Imprisonment Schemes"}

SBR's main point of attack on empirical desert is to challenge what they see as the three hypotheses on which empirical desert relies. But as Part II demonstrates, all of those challenges fall flat. Nothing in any of their studies undermines empirical desert, and in fact, despite their best efforts, their own studies actually confirm empirical desert's crime-control benefits.

But if those SBR criticisms are unsupported, what other sorts of criticisms of empirical desert can they offer? Their only other attack is, almost in passing, to refer to the "deleterious effects of reliance on desert as the linchpin of punishment policy effects ranging from unusually harsh sentences to expensive imprisonment schemes." ${ }^{131}$ But in support of these claims they offer no support nor even a citation to other authority. Their claim stands as simply an expression of their own personal opinion, without even an attempt at documentation. The problem for them, of course, is that there is no support for such criticisms. Indeed, these claims were offered and easily refuted many years ago at the start of the empirical desert debate, as SBR must know since they cite for other purposes the very articles on point. ${ }^{132}$ Yet they feel free to throw out the old discredited accusation without even citation.

The somewhat obvious response to such claims is this: Literally by definition empirical desert cannot produce "unusually harsh sentences." ${ }^{133}$ It cannot even produce somewhat harsh sentences, because sentences that are harsh cannot by definition be consistent with the community judgements of justice. Indeed, empirical desert is the one and only among all utilitarian distributive principles that can never produce harsh sentences. (Unless, SBR mean by harsh sentences those that they, SBR, personally think are harsh although the rest of the community does not. But, presumably, no one would take seriously this standard for sentence harshness.)

129 Id. at 79. See also supra notes 124-25.

130 See supra pp. 23-28.

131 SBR, supra note 2, at 79 .

132 Intuitions, supra note 8, at 41-43; Paul H. Robinson, Competing Conceptions of Modern Desert: Vengeful, Deontological, and Empirical, 67 CAMBRIDGE L.J. 145, 156-57, 159160 (2008); DISTRIBUTIVE PRINCIPLES, supra note 1, 145-47, 149-52, 202-04.

133 Note that the term "harsh" has only a desert meaning - "repugnant or roughly offensive to the feelings; severe, rigorous, cruel, rude, rough, unfeeling," THE OXFORD ENGLISH DICTIONARY (updated online version) - not a prevention meaning. 
SBR may have confused themselves here by looking not at empirical desert what empirical research by social scientists has revealed about the principles of justice instantiated in lay judgements of justice - but at politicians' "law and order" rhetoric. But it is hard to read the empirical desert literature and come away with that mistaken view. We know of no claim by any empirical desert proponent that the distributive principle of empirical desert is to be determined by politicians' rhetoric or even the results of it. Indeed, the Disutility studies have shown overwhelmingly and conclusively that the crime-control doctrines pressed by politicians dramatically conflict with lay persons' intuitions of desert, doctrines including three-strikes and other habitual offender statutes, high penalties for drug offenses, adult prosecution of juveniles, abolition or narrowing of the insanity defense, strict liability offenses, and felony murder.

Perhaps a bit embarrassing for SBR, and their "individual prevention" principle, is the fact that, as the Disutility article documents, every one of these doctrines exists because of the coercive crime-control justifications offered for it; each doctrine was designed to incapacitate dangerous offenders or to provide general deterrence or, in most cases, both. ${ }^{134}$ The Disutility studies document the dramatic nature of these doctrines' deviation from empirical desert. ${ }^{135}$ If empirical desert were the distributive principle, none of these doctrines would exist. But SBR would have us believe that it is empirical desert that generates "unusually harsh sentences."

Similar is SBR's claim that empirical desert produces "expensive imprisonment schemes." Nothing in empirical desert requires the use of imprisonment at all, or any other particular method of punishment. Empirical desert cares that offenders receive the amount of punishment they deserve, and cares little about the method by which it is imposed. As the empirical studies show, lay persons have in their heads "punishment bite" ratios among punishment options: fines, probation, house arrest, weekends in jail, intensive supervision, and a variety of others. ${ }^{136}$ Any of these options, or others, ${ }^{137}$ can impose the deserved punishment.

As with SBR's claim of "unusually harsh sentences," their claim of "limited to imprisonment" was made and refuted years ago in the empirical desert debate, yet SBR feel free to throw out the accusation again, without documentation or citation.

134 Disutility of Injustice, supra note 22, at 1949-61.

135 Id. at 1961-78.

136 See, e.g., R. E. Harlow et al., The Severity of Intermediate Penal Sanctions: A Psychophysical Scaling Approach for Obtaining Community Perceptions, 11 J. QUANTITATIVE CRIMINOLOGY 71, 85 (1995); George Gescheider et al., Psychophysical Measurement of the Judged Seriousness of Crimes and Severity of Punishments, 19 BULL. PSYCHONOMIC SOC'Y 275-78 (1982); Deborah Buchner, Scale of Sentence Severity, 70 J. CRIM. L. \& CRIMINOLOGY 182 (1979); Maynard L. Erickson \& Jack P. Gibbs, On the Perceived Severity of Legal Penalties, 70 J. CRIM. L. \& CRIMINOLOGY 102 (1979); Leslie Sebba, Some Explorations in the Scaling of Penalties, 15 J. RES. CRIME \& DELINQ. 247 (1978). For a real-world example of a punishment equivalency table, see Paul H. Robinson et al., Codifying Shari'a: International Norms, Legality and the Freedom to Invent New Forms, 2 J. COMP. L. 1, 50 (2007).

137 For example, community service, treatment programs, restitution, curfew, occupational disqualification, banishment, shaming practices, and virtually any other method of imposing suffering (subject to constitutional constraints). 


\section{SBR's Proposal for a Distributive Principle Based Upon "Individual Prevention" Within Limiting Retributivism}

Rather than empirical desert, SBR propose a distributive principle of what they call "individual prevention"138 operating within limiting retributivism. They say, for example, that "unless it represents a radical departure from desert," they would have punishment focus on "prevention ... through the mechanisms of specific deterrence, incapacitation, and rehabilitation." 139 Similarly, they explain, "the best way to reconcile retributive and preventive goals is probably through some sort of limiting retributivism, or what we are calling preventive justice, which allows utilitarian considerations to have significant impact within a range established by retributive principles." 140

SBR claim that their studies here not only undermine empirical desert but also support this proposed principle of "individual prevention."141 Yet, not only do the studies not undermine empirical desert, as Part II has shown, neither do they offer support for SBR's "individual prevention" proposal. Further, their proposal is plagued by irrationalities and internal inconsistencies, which raise puzzling, and troubling, questions.

\section{Irrationalities and Inconsistencies in SBR's Proposal: The Need to Dress "Individual Prevention" as Something Other than Pure Preventive Detention}

\section{Consider what their proposed principle provides and how it functions.}

The Failure to Define the Interrelation Among Special Deterrence, Rehabilitation, and Incapacitation of the Dangerous. Note that SBR claim that special deterrence, rehabilitation, and Incapacitation of the dangerous are all part of their proposed distributive principle. But what, exactly, is their interrelation? Is there some instance in which SBR would follow special deterrence in conflict with

138 SBR, supra note 2, at 179. SBR give this a retail label of "preventive justice," id., but we cannot bring ourselves to be complicit in their attempt to dress up their principle as if it were justice. As we detail at infra pp. 45-48, their proposed principle very much conflicts with justice - both empirical desert and deontological desert - and giving it that label only tends to hide this fact. It only confirms that SBR understand that they must use that dressing because of the detrimental effects to their selling principle if they advertise its conflict with desert. If they think desert ought to be violated for crime-control purposes, why not be open about it? Why try to hide it as if their principle were actually doing justice? Why don't they call their principle "preventive detention"?

139 Id. at 123. See also supra note 128.

140 Id. at 122. SBR would "pursue utilitarian goals directly," but only within desert "boundaries beyond which real de-legitimization of the government and its laws occurs." Id. at 124. "From a utilitarian perspective, a system aimed at prevention, only loosely constrained by desert, may well be optimal." Id. at 87.

141 Id. at 79 . See also id. at 87 ("[O]ur research suggests that the best way to reconcile the tension between desert and preventive considerations may well be to focus primarily on the latter rather than the former."); id. at 103 ("Study 3 suggests that, while failing to adhere to desert might cause some noncompliance, failing to adhere to [individual prevention] goals could cause even more noncompliance."). 
dangerousness, or follow rehabilitation in conflict with dangerousness? At no point do SBR seem to admit this possibility.

Indeed, Christopher Slobogin has had a long-standing interest in a criminal justice system focused strictly on dangerousness. In 2003, he announced that a sentencing system, "based entirely on dangerousness," was entirely permissible. ${ }^{142}$ In 2005, when he first introduced his"individual prevention" principle, Slobogin said: "The criminal law ought to embrace the dangerousness criterion, with the significant caveat that it do so wholeheartedly rather than in the halting manner it has exhibited to date."143 While his"individual prevention" was said to also include rehabilitation and special deterrence ${ }^{144}$ he described the system as one in which "intervention based on dangerousness [would be] the government's only liberty-depriving response to anti-social behavior." ${ }^{145}$ "[N]o minimum or maximum terms would be imposed." ${ }^{146} \mathrm{He}$ continued to propose a system of indeterminate sentencing, in 2011, in which "preventive detention would take place within the criminal justice system .... [T]he nature and duration of the sentence imposed after the conviction would depend ... upon the probability and magnitude of the risk posed by the offender and the means available to diminish the risk." ${ }^{147}$ His system of indeterminate sentencing would "base disposition explicitly on risk assessment and risk management, with release or conditional release dependent on periodic review of the degree of risk posed." ${ }^{148}$

SBR's undisclosed assumption appears to be that all three of the principles special deterrence, rehabilitation, and incapacitation of the dangerous - in practice collapse into dangerousness because, after all, there is no need for rehabilitation or for special deterrence unless the offender is presently dangerous.

But SBR's assumption is false. Each of the three - special deterrence, rehabilitation, and incapacitation of the dangerous - set different punishment criteria. In considering a given case under each of them alternately, one would come to different dispositions as a result of their different criteria. Special deterrence looks to what punishment the specific offender at hand needs to deter him in the future.

Rehabilitation looks to what treatment programs are available, or not, that could rehabilitate the offender so as to take away his interest in committing an offense in the future. Both of these inquiries are different from the pure dangerousness assessment and each would generate a sentence that was different from a sentence based upon pure dangerousness. Under a distributive principle of rehabilitation, for example, one could not justify taking control if no rehabilitation is possible: rehabilitation would provide no sentence. But SBR presumably would impose a sentence nonetheless. Under their principle, the dangerousness principle trumps the rehabilitation principle.

\footnotetext{
33-34 (2003).

${ }^{143}$ Christopher Slobogin, The Civilization of the Criminal Law, 58 VAND. L. REV. 121 , 122 (2005).

144 Id. at 128.

145 Id. at 127.

146 Id. at 168 .

147 Christopher Slobogin, Prevention As the Primary Goal of Sentencing: The Modern
}

${ }^{142}$ Christopher Slobogin, A Jurisprudence of Dangerousness, 98 NW. U. L. REV. 1 , Case for Indeterminate Dispositions in Criminal Cases, 48 SAN DIEGO L. REV. 1127, 1152 (2011).

148 Id. at 1129. In such a system, "dispositions should be proportionate to risk." Id. at 1135. 
That is, SBR's "individual prevention" proposal is one where apparently it is dangerousness that will always control, where the disposition that special deterrence or rehabilitation might suggest is washed out by the dangerousness principle: if the offender remains dangerous at the conclusion of his special deterrence or rehabilitation term, he will continue to be detained; if he becomes nondangerous before the end of the special deterrence or rehabilitation term, then there is no reason to detain. But if special deterrence and rehabilitation can never trump dangerousness, then they are not in truth part of the ultimate principle, but only window dressing. ${ }^{149}$

Slobogin has had few takers for his notion of substituting a preventive detention system for a criminal justice system, but if he can dress it up as something other than pure preventive detention, then it might seem more attractive. ${ }^{150}$ SBR's supposed three-part distributive principle - "individual prevention" - thus simply provides useful window dressing to make it look like something other than preventive detention's pure dangerousness. SBR's failure to define the interrelation among the three principles helps hide that fact. ${ }^{151}$

The same strategy may be at the root of SBR's somewhat odd treatment of general deterrence, as well as their claim to be adopting a sort of limiting retributivism. These are the subjects of the next two subsections.

Dropping General Deterrence. As utilitarians, one would expect that SBR would be anxious to include general deterrence in their proposed distributive principle. When the prerequisites exist for general deterrence to work, a single case has the potential to produce enormous crime-control benefit, perhaps influencing thousands or

149 For example, one does not need rehabilitation as a distributive principle for criminal liability and punishment in order to have correctional officials try to rehabilitate offenders.

Adopting rehabilitation as a correctional policy will do that, without rehabilitation having any part of the distribution principle for punishment.

150 This invites reflection on Slobogin's curious evolution on the relevance of desert. In 2005, he made it clear that desert would play no role at sentencing: "no minimum or maximum terms would be imposed," he said, since "disposition should be based on risk management principles." Slobogin, supra note 143, at 168. By 2011, he said desert might set high upper sentencing limits, Slobogin, supra note 147, at 1165 , though he repeatedly distinguished his proposal from limiting retributivism, id. at 1129-30,1154, 1165, 1167. In his latest article, he now claims to adopt a "sort of limiting retributivism": desert doesn't just set high upper limits - he would follow it whenever it would offer greater utility than his preferred principle of individual prevention. See supra notes 126-28 and accompanying text. These expressions of growing support for desert might well improve the marketability of his (strategically labeled) "preventive justice" regime, but, underneath the veneer, the proposal remains fundamentally centered on dangerousness.

151 Note also that, without a principled way to order SBR's three factors, we are likely to end up with the sort of ad-hoc balancing that will inevitably been seen and experienced as arbitrary. Such a system is likely to undermine the system's moral credibility - and its adjudication "legitimacy," in Tom Tyler's sense - leading to an especially pernicious downward spiral.

The need to define the interrelation among the principles in a hybrid system has been part of the distributive principle literature for some time. See, e.g., DISTRIBUTIVE PRINCIPLES 719; Paul H. Robinson, Hybrid Principles for the Distribution of Criminal Sanctions, 82 NW. U. L. REV. 19 (1987). 
millions of people at relatively little cost to the system. Yet SBR expressly bar reliance upon general deterrence. ${ }^{152}$ Why might that be?

They claim that general deterrence does not work as a principle for determining who should be punished how much, ${ }^{153}$ but the authority they cite for this preposition does not support their conclusion. ${ }^{154}$ On the other hand, Robinson has been an outspoken critic of general deterrence and has shown, in several articles ${ }^{155}$ and in his Distributive Principles book, ${ }^{156}$ why general deterrence makes a poor distributive principle. It is not that general deterrence does not work. It does work, but only when certain prerequisites exist, which they commonly do not. But sometimes they do exist, and when they do the good crime-control utilitarian must consider general deterrence as part of her distributive principle.

It is for this reason that Robinson leaves open this possibility in the principle he proposes at the conclusion of his Distributive Principles book. He believes that the occasions when a general deterrence effect exist from doctrinal manipulation are limited, and, even when they exist, the cost of the deviation from empirical desert may outweigh the general deterrence benefit. (General deterrence can only provide a greater deterrent effect than is already inherent in an empirical desert punishment by deviating from empirical desert, and general deterrence is at its weakest in such deviation situations because it is in precisely these cases of injustice that the general deterrence program is most likely to be subverted by participants in the criminal justice system. ${ }^{157}$ ) But rational utilitarian analysis requires that Robinson leave open the

152 See SBR, supra note 2, at 79 n.5, 81 n.11.

153 Id. at $81 \mathrm{n} .11$ ("The assumption throughout this Article is that, while some sort of punishment is crucial to deterring crime, no particular punishment is necessary to ensure that goal."). However, SBR appear to contradict themselves later in the article. After finding that test subjects were less likely to commit an offense after being exposed to sentences far harsher than their own recommended sentence, SBR speculate that this result might be attributable to general deterrence. Id. at 107. But this is inconsistent with their earlier statement that general deterrence simply doesn't work. If they really believe it never works, they cannot entertain the idea that it might explain an increase in crime control. On the other hand, if they do believe it can work (even if under only limited circumstances), why, as committed utilitarians, would they exclude it wholesale from their "individual prevention" theory?

154 SBR cite Michael Tonry, Purposes and Functions of Sentencing, 34 CRIME \& JUST. 1, 28 (2006), and quote him as saying "[i]maginable increases in severity of punishments do not yield significant (if any) marginal deterrent effects." SBR, supra note 2, at 79, 81 n.11 (2013). But a distributive principle of general deterrence would do much more than increase the general severity of punishment. For example, it might take measures to increase the (perceived) probability of punishment and reduce the (perceived) delay between violation and punishment. Moreover, rather than simply increasing all punishment amounts, it would set punishment severity for each offense at the most efficient level required to optimize deterrence. The resulting punishment amount might be high or low or anything in between, depending on the particular characteristics of the offense in question. For a detailed discussion of the operation of general deterrence, see DISTRIBUTIVE PRINCIPLES, supra note 1, at 21-71.

155 Paul H. Robinson \& John M. Darley, Does Criminal Law Deter? A Behavioural Science Investigation, 24 OXFORD J. LEGAL STUD. 173 (2004); Paul H. Robinson \& John M. Darley, The Role of Deterrence in the Formulation of Criminal Law Rules: At its Worst When Doing its Best, 91 GEO. L.J. 949 (2003).

156 DISTRIBUTIVE PRINCIPLES, supra note 1, at 21-97.

157 Paul H. Robinson \& John M. Darley, The Role of Deterrence in the Formulation of (continued...) 
theoretical possibility that general deterrence could in some instances produce gains that outweigh the costs of its deviation from desert. SBR foreclose that possibility, without ever explaining how this can be justified on utilitarian grounds.

This is a bit of an ironic twist. SBR purport to want to follow Norval Morris' concept of limiting retributivism, recently adopted by the American Law Institute as an amendment to the Model Penal Code. However, Morris accepted and advocated reliance upon general deterrence, ${ }^{158}$ which SBR exclude, and largely rejected reliance upon special deterrence, rehabilitation, and incapacitation of the dangerous as a distributive principle, ${ }^{159}$ which SBR rely upon exclusively.

As noted previously, ${ }^{160}$ Slobogin has had a long-running interest in a system based on pure dangerousness - a pure preventive detention system. It is not farfetched to assume that Slobogin's move to keep most of the coercive crime-control principles, but to reject general deterrence, is simply maneuvering that he hopes will get where he really wants to go: to focus exclusively on dangerousness. Unlike the other coercive crime-control principles - special deterrence and rehabilitation - general

157 (...continued)

Criminal Law Rules: At its Worst When Doing its Best, 91 GEO. L.J. 949, 983-85 (2003).

158 MORRIS, supra note 48, at 60 (arguing that punishment can be increased where the increase is "necessary to achieve socially justified deterrent purposes, and the punishment of this offender is an appropriate vehicle to that end"); id. at 75 ("The criminal law has...educative and deterrent functions in relation to potential criminals,... which bear upon the determination of the proper punishment."); id. at 76 ("Principles of desert and of deterrence are relevant" to "imposing or prolonging a term of imprisonment").

159 For Morris' rejection of specific deterrence, see id. at 76-77 ("[I]n [] advocating a general deterrent justification for the imposition of a prison sentence, I intend to exclude the fear of repetition of crime by this criminal. The concept is that of general deterrence, not special deterrence: the deterrence of all who might be inclined to do what he has done. It involves no predictions as to his future behavior; it does not seek to imprison him so that he more than others will not do it again.").

For his rejection of incapacitation of the dangerous, see id. at 62 ("'[D]angerousness' as a prediction of future criminality is an unjust basis for imposing a sentence of imprisonment... 'Dangerousness' must be rejected for this purpose, since it presupposes a capacity to predict future criminal behavior quite beyond our present technical ability."); id. at 63 ("The concept of dangerousness for sentencing purposes is an equivocal principle that leads to gross injustice."); id. at 73 ("[A]s a matter of justice we should never take power over the convicted criminal on the basis of unreliable predictions of his dangerousness.); id. at 76 (Predictions of dangerousness are...to be rejected as a basis for imposing or prolonging a term of imprisonment."). Believing that dangerousness assessments would unavoidably creep into the criminal justice system, whether formally permitted or not, Morris later said that reliable risk predictions might justify an increase in sentence severity under very narrow circumstances. See Richard S. Frase, Limiting Retributivism, in THE FUTURE OF IMPRISONMENT 83, 87 (Michael Tonry ed., 2004).

For his rejection of rehabilitation as a distributive principle, see MORRIS, supra note 48, at 18 ("The sentencing judge should never extend a term of imprisonment, or impose a term of imprisonment, on the basis that the offender needs it for his retraining. That is none of the judge's business."). See also Richard S. Frase, Limiting Retributivism, in THE FUTURE OF IMPRISONMENT 83, 87 (Michael Tonry ed., 2004) ("Morris concluded that rehabilitation is not a reason either to impose or to extend a prison sentence, and that all in-prison treatment programs must be voluntary and not linked to the timing of release.").

160 See supra text accompanying notes 142-51. 
deterrence cannot be made to quietly collapse into dangerousness, so it must be simply dropped.

Limiting "Individual Prevention" Principles to Determine Sentences But Not Liability Rules. An easy way to alienate essentially all theorists and practitioners would be to press pure preventive detention so far as to not require proof of commission of an offense, or to drop a requirement of any culpability or to bar excuses: think Tom Cruise in Minority Report, but without the ability to accurately predict future criminality. No one would want to live under a system where "punishment" is imposed upon a mere prediction of future criminality. (We put "punishment" in quotes at this point because, once one has dumped moral blameworthiness as the primary determinant for sanctions, in favor of prevention, it becomes awkward to refer to those sanctions as "punishment," which is commonly defined to refer to deserved suffering for a past offense. ${ }^{161}$ It would presumably be more accurate to speak of SBR's new system as imposing "preventive restraint."162) SBR are not unaware of the toxicity of such an approach and the current SBR proposal would limit its application of "individual prevention" to sentencing only, without application to liability rules. ${ }^{163}$

But while that limitation may be useful for avoiding the toxicity of their preventive detention proposal, it lands SBR in a somewhat irrational position. Requiring that some criminal harm or evil actually occur makes good sense, even for pure preventive detention. (The occurrence of the harm or evil helps confirm it is not just a theoretical possibility that the detained person could commit an offense.) But in adopting this safeguard and trying to use the criminal justice system for preventive detention, SBR end up having to swallow much more than they want or can logically justify. By agreeing to back out of the entire liability stage - which assigns liability for a specific grade offense - they end up having to keep their hands off a wide-variety of doctrines that go far beyond assuring a criminal harm or evil has occurred and that have everything to do with dangerousness.

For example, on what grounds can SBR justify giving an insanity defense to a person whose mental illness has caused his offense? On what grounds would SBR justify giving the standard grading discount for a failed attempt, where this failure occurred only because of the bad luck of the offender (thus making clear he is no less

161 To "punish" is "to cause (a person) to undergo pain, loss, or suffering for a crime or wrongdoing.” WEBSTER'S NEW WORLD COLLEGE DICTIONARY 1180 (2d ed. 1959).

162 Indeed, Slobogin seems to concede as much in his earlier work. In 2003, he says: "Criminal punishment is based solely upon a conviction for an offense and can occur only if there is such a conviction. Preventive detention is based solely upon a prediction concerning future offenses and can occur only if there is such a prediction. Therefore, preventive detention is not criminal punishment. Indeed, the concept of 'punishment' for some future act is incoherent." Slobogin, supra note 142, at 12. (He later attempts, unconvincingly, to reconcile this statement with his approval of an indeterminate sentencing regime "based entirely on dangerousness." Id. at 32-34.) See also Christopher Slobogin \& Mark Fondacaro, Rethinking Deprivations of Liberty: Possible Contributions from Therapeutic and Ecological Jurisprudence, 18 BEHAV. SCI. \& L. 499, 504 n.24 (2000) ("Punishment is a reaction to a past act, not an attempt to prevent a future one."). Two years later, he openly (and repeatedly) contrasts "the punishment model of criminal justice" with his proposed "preventive model of criminal justice" or "prevention model of intervention." Slobogin, supra note 145, at 122, 139, 165, 166.

163 SBR, supra note 2, at 79 ("[W]hile liability rules should still depend primarily on desert, punishment rules [should] focus on the utilitarian goals of specific deterrence, rehabilitation, and incapacitation ('individual prevention' goals)."). 
dangerous than if he had succeeded)? Why is dangerousness to be the master of sentencing but ignored in liability and grading? The code-sentencing distinction can have a practical and historical basis for practitioners, but it is hard to see how it can have a principled basis on SBR's account.

Indeed, the bulk of a criminal code's provisions are essentially grading judgements, usually based upon desert. For example, on what ground could SBR justify giving the extreme emotional disturbance mitigation that reduces murder to manslaughter, with its dramatic reduction in the maximum sentence? One could properly assume that an offender's extreme emotional disturbance that has caused a killing would be just the sort of condition to signal greater dangerousness, which should argue for greater criminal justice control, not less. A large percentage of the provisions of a criminal code perform such a grading function, based on factors that have nothing to do with "individual prevention." 164 How could SBR rationally justify excluding all of them from the reach of their proposed distributive principle? If they believe in the superiority of their "individual prevention," why not apply it to all doctrines of mitigation, excuse, and grading?

The answer is probably, again, a need to maneuver to obscure. SBR may calculate that people might swallow their "individual prevention" principle if it is limited in its effects and if its effects can be sufficiently obscured as to still be able to hide under the cloak of "criminal justice." Applying their principles in a more open fashion - as in denying an insanity defense, or grading failed attempts the same as the completed offense - would be so loathsome to people as to quickly kill their proposal's chances. Better to take the unprincipled approach, if that is what is necessary for camouflage.

\section{SBR's Claimed Adherence to Limiting Retributivism, and the Problem of "Unusually Harsh Sentences"}

SBR claim that they are adopting a sort of limiting retributivism, ${ }^{165}$ but, in fact, the same window dressing strategy is at work here. As noted previously, limiting retributivism is a popular concept at the moment, having been recently adopted by the American Law Institute as part of their only amendment to the Model Penal Code in the half century since its promulgation. If SBR's "individual prevention" is restricted by limiting retributivism, it certainly is nothing one need be concerned about, right? Wrong. The truth is that, despite SBR's attempt to associate themselves with limiting retributivism, a close look shows that their proposed "individual prevention" is not in fact limited in this way.

As Part I explained, the new amendment to Model Penal Code Section $1.02(2)(a)(i)$ requires that punishment be "within a range of severity proportionate to the gravity of offenses, the harms done to crime victims, and the blameworthiness of

164 Model Penal Code And Commentaries, Part 1: General Provisions $\S \S 1.01$ to 2.13 , at $\S 1.02 \mathrm{cmt} 2(\mathrm{e})$ (1985) ("The provisions governing the definition of offenses not only serve to describe the conduct that the penal law makes criminal but also reflect a legislative grading of offenses, differentiating serious and minor derelictions and, within each class, offenses of greater or lesser gravity. These distinctions have important bearing on the sentencing and treatment of offenders...") For a general discussion of the liability assignment and grading functions of criminal law, see Paul $\mathrm{H}$. Robinson, A Functional Analysis of Criminal Law, 88 NW. L. REV. 857 (1994).

165 See supra text accompanying notes $138-40$. 
offenders" - classic desert. Subsection (2)(a)(ii) allows the traditional coercive crimecontrol principles (including SBR's, as well as general deterrence) to be consulted but limits their operation to "within the boundaries of sentence severity permitted in subsection (a)(i)" - that is, they can never violate desert. ${ }^{166}$

SBR's proposed "individual prevention," in contrast, does allow desert to be violated - injustice can be done, in the name of prevention. "Individual prevention" holds back only if the injustice would have a sufficiently dramatic criminogenic effect: It must be a "radical departure from desert"; 167 less than radical departures from desert are fine. It must cause a "real delegitimization of the government and its laws;"168 any less egregious, run-of-the-mill subverting of the criminal law's moral credibility is no problem. This is not limiting retributivism, either as conceived by Norval Morris and others or as adopted by the American Law Institute.

Indeed, this is in many respects just the reverse of limiting retributivism. Under limiting retributivism, desert is master, and can never, under any circumstances be violated, no matter how attractive the preventive purpose. Under "individual prevention," dangerousness is running the show. Following desert despite its conflict with dangerousness is a theoretical possibility but certainly, in SBR's minds, probably only that. ${ }^{169}$

In the end, rather than limiting retributivism, we are left with what one might call "threshold preventionism," a sort of dark mirror version of Michael Moore's threshold deontology view. ${ }^{170}$ On this account, we start, and usually end, with preventive measures, and move away from them towards desert only when certain very dire results are foreseen. Whatever this view is, it is not a form of limiting retributivism. And no doubt would be seen as appalling by the American Law Institute's Model Penal Code drafters, who would never let punishment violate desert.

The dramatic effect of what SBR have in mind does not stop with their distributive principle. Their system is one in which sentences would provide only "broad ranges" that would allow parole commissions to determine the actual punishment at some later indeterminate date. ${ }^{171}$ In his 2011 piece, Slobogin explains, "once a person is convicted of an offense, the duration and nature of sentence should be based on a back-end decision made by experts in recidivism reduction, within broad ranges set by the legislature."172 "[R]isk would be determined at the back end by an expert panel rather than at the front end by a judge."173

166 Model PenAl Code: SeNTENCING § 1.02(2)(a) (approved May 16, 2007).

167 SBR, supra note 2 , at 81,123 .

168 Id. at 124.

169 Robinson's empirical desert is the mirror image of SBR's "individual prevention": Deviation from desert for coercive crime-control purposes is a theoretical possibility, but perhaps only that, depending upon how the numbers work out. As discussed in Distributive Principles, intentional deviations from desert are extremely damaging to the system's moral credibility for they give the citizen reason to doubt the motivations of all of the criminal justice system's rules. DISTRIBUTIVE PRINCIPLES, supra note 1, at 198-200.

170 Michael MoORe, Placing Blame: A TheORY OF THE CRIMINAL LAW 80 (2010).

171 SBR, supra note 2, at 122 .

172 Slobogin, supra note 147, at 1130.

173 Id. at 1165 . Similarly, he explains in his 2011 article, "release decisions [would] depend on back-end calculations by correctional officials." Id. 
SBR have it right that this is a world in which "[d]esert theorists would not be happy," ${ }^{174}$ but it is also a world incompatible with the American Law Institute's limiting retributivism principle and in conflict with the dominant sentencing movement of the past several decades. ${ }^{175}$ Many states have reduced sentencing discretion in favor of guidelines, ${ }^{176}$ have abolished or reduced indeterminate sentences, ${ }^{177}$ and have brought citizens more into the process through restorative justice programs, rather than pushing them out by leaving the decision to back-end experts. ${ }^{178}$ While SBR have attempted to

174 Id. at 122.

175 "Beginning in about the early 1980s, a large systemic change in sentencing law and practice occurred. Legislatures across the country began to abolish indeterminate sentencing and extensive judicial discretion in favor of determinate sentencing guidelines and mandatory minimum sentences." Benjamin J. Priester, Structuring Sentencing: Apprendi, the Offense of Conviction, and the Limited Role of Constitutional Law, 79 IND. L.J. 863, 869 (2004).

176 See Harris v. United States, 536 U.S. 545, 558 (2002) ("In the latter part of the 20th century, many legislatures, dissatisfied with sentencing disparities among like offenders, implemented measures regulating judicial discretion."); CASSIA SPOHN, HOW DO JUDGES DECIDE?: THE SEARCH FOR FAIRNESS AND JUSTICE IN PUNISHMENT 230 (2d ed. 2009) (noting that, by 2004 , seven states had introduced voluntary sentencing guidelines, and eleven states had adopted presumptive sentencing guidelines). The federal system, of course, has also adopted sentencing guidelines, while the American Law Institute is set to do likewise. UNITED STATES Sentencing Commission, Guidelines Manual (2012); Model PenAl Code: Sentencing § $6 B .02$ (Tentative Draft No. 1, 2007). This is consistent with the policy of the American Bar Association, which has supported sentencing guidelines since at least 1994. AMERICAN BAR ASSOCIATION, STANDARDS FOR CRIMINAL JUSTICE: SENTENCING, at standards 18-2.5(b), 18-4.3, 18-4.4 (3d ed. 1994).

177 While "every jurisdiction had indeterminate sentencing in 1970," SPOHN, supra note 176, at 230, "[a]bout one-third of U.S. jurisdictions have [now] abrogated the prison-release discretion of the parole board for most cases-a number that has been slowly growing over the past several decades," MOdEL PENAL CODE: SENTENCING RePS. DISCUSSION, at 2 (Discussion Draft No. 3, 2010). See also TIMOTHy HUgheS, DoRIS WILson, \& AlLEN BECK, DePT. OF Justice, BUREAU OF JUSTICE STATISTICS, TRENDS IN STATE PAROLE, 1990-2000, at 1 (2001) (noting that, by the end of 2000 , sixteen states had abolished parole for all offenses, while another four states had abolished it for certain ones). Moreover, in a majority of the country, the proliferation of truth-in-sentencing laws has dramatically reduced the disparity between sentences imposed and actual time served. PAULA M. DITTON \& DORIS JAMES WILSON, U.S. DEPT. OF JUSTICE, BUREAU OF JUSTICE STATISTICS, TRUTH IN SENTENCING IN STATE PRISONS 2-3 (Jan. 1999) (finding that, in 1998, offenders in twenty-seven states and the District of Columbia served at least $85 \%$ of their sentence). The indeterminate approach to sentencing has also been rejected by the federal system, the American Law Institute, and the American Bar Association. Stephen Breyer, Federal Sentencing Guidelines Revisited, 11 FED. SENTENCING REP. 180 (1999) (discussing the Sentencing Reform Act of 1984 and its abolition of the indeterminate system of federal sentencing); MODEL PENAL CODE: SENTENCING § 6.06(4)-(5) and comment e (Tentative Draft No. 2, 2011); AMERICAN BAR ASSOCIATION, STANDARDS FOR CRIMINAL JUSTICE: SENTENCING, at standards 18-2.5, 18-3.21(g), and 18-4.4(c) (3d ed. 1994).

178 The role of back-end experts has been in decline for several years now. JEREMY TRAVIS \& SARAH LAWRENCE, URBAN INST. JUSTICE. Policy CTR., BEYOND THE PRISON GATES: THE STATE OF PAROLE IN AMERICA 4 (2002), available at http://www.urban.org/UploadedPDF/310583_Beyond_prison_gates.pdf (in 1976,65\% of state prison releases were by discretionary parole; by 1999, that number had dropped to $24 \%$ ). Restorative justice programs, on the other hand, have only gained in popularity since their 
dress up their "individual prevention" as something new and different and comfortable, what they propose is a more extreme version of the (widely criticized) punishment theory of the 1960s.

One of the reasons that the dangerousness-driven punishment theory of the 1960s has become less attractive is that it generated a host of doctrines that produced "unusually harsh sentences," as under the three-strikes rule and cases like Rummel's life imprisonment for air-conditioning fraud - which is why it is so outrageous that SBR would try to throw that mud on empirical desert. As the Disutility study demonstrates, lay subjects - empirical desert - find these preventive-detention-based doctrines to be outrageously unjust. If empirical desert were the distributive principle, none of these doctrines would exist. But SBR would have us believe that it is empirical desert that generates "unusually harsh sentences," from which SBR's "individual prevention" principle is here to save us.

It is unfortunate that SBR have tried to dress up their proposal as something it is not. It is also unfortunate that they have chosen to advance their scheme by hurling false accusations at empirical desert. What would have been more useful would be their open disclosure and justification of their proposed principle. What is it exactly that SBR offer in support of their "individual prevention"?

\section{SBR's Claimed Support for their "Individual Prevention" Proposal}

SBR claim that, compared with empirical desert, their preventive distributive principle "is a superior approach from a utilitarian perspective." ${ }^{179}$ But why? While they want to try to trivialize the crime-control costs of deviating from empirical desert - "A failure to track community members' views does not have a significant or lasting effect

\section{8 (...continued)}

introduction in the late 1970s. Although they are relatively new on the scene, "they are known today to be developing in nearly every state," ranging "from small and quite marginal programs in many communities to a growing number of state and county justice systems that are undergoing major systemic change." Mark S. Umbreit et al., Restorative Justice: An Empirically Grounded Movement Facing Many Opportunities and Pitfalls, 8 CARDOZO J. CONFLICT RESOL. 511,521 (2007). Of the many restorative processes in use, victim-offender mediation programs have proved particularly popular. The American Bar Association has officially endorsed them, for example, recommending their use in courts around the country and providing guidelines for their operation and development. AMERICAN BAR ASSOCIATION, AMERICAN BAR ASSOCIATION ENDORSEMENT OF VICTIM-OFFENDER MEDIATION/DIALOGUE PROGRAMS (1994), available at http://www.vorp.com/articles/abaendors.html. Indeed, as of 1996, approximately 300 victimoffender mediation programs existed throughout the United States, with the average adult program receiving around 76 referrals per year, and the average juvenile program receiving 136. MARK S. UMBREIT ET AL., U.S. DEPT. OF JUSTICE, OfFICE FOR VICTIMS OF CRIME, NATIONAL SURVEY OF VICTIM-OFFENDER MEDIATION PROGRAMS IN THE UNITED STATES 1 (2000), available at https://www.ncjrs.gov/ovc archives/reports/restorative justice/restorative justice ascii pdf/ncj1 76350.pdf. By 2001, such programs could be found on the statute books of at least twenty-nine different states. MARK S. UMBREIT ET AL., CENTER FOR RESTORATIVE JUSTICE AND PEACEMAKING, LEGISLATIVE StATUTES ON VICTIM-OFFENDER MEDIATION: A NATIONAL REVIEW (2001), available at http://www.cehd.umn.edu/ssw/rjp/resources/Program_Development/Legislative_Statutes_VOM _National_Review.pdf.

${ }^{179}$ SBR, supra note 2 , at 79-80. 
on their willingness to be law-abiding citizens"180 - they must and do repeatedly concede, as noted previously, ${ }^{181}$ that there are indeed such deviation costs.

If they concede that there are crime-control costs to deviating from empirical desert, then their "individual prevention" regime can hardly have greater crime-control power unless it is shown to have crime-control benefits and, further, crime-control benefits that exceed its crime-control costs. Yet they offer no evidence of this, nor explanation, nor even a cite to another source that might support such a claim. What we do have is the Disutility study that casts considerable doubt on the utility of "individual prevention": preventive measures that deviate from desert undermine the law's moral credibility and, thereby, its mechanisms of normative crime-control. What evidence do SBR offer that their proposal's crime-control benefits are so great as to outweigh these demonstrated crime-control costs?

Their studies are aimed primarily at attempting to disprove or to trivialize the crime-control cost of deviating from empirical desert, which they fail to do. Is there other support for the crime-control benefits of the "individual prevention" proposal? There is a rich literature on issues relating to the crime-control effectiveness of such preventive-detention regimes. For example: What is the current reliability of predictions of future crime by an individual? Commonly very low. ${ }^{182}$ What is the false positive rate of such predictions? Commonly very high. ${ }^{183}$ Why would we want to assume, without any showing from SBR, that the specific preventive detention scheme that they propose would somehow overcome the gross inefficiencies and unfairness that currently plague preventive detention proposals generally? ${ }^{184}$

And even if they could show net crime-control benefits from "individual prevention," they need to do more to support their claim: they need to show that those crime-control benefits are sufficiently great as to outweigh the crime-control costs of deviation from desert that they concede exist. To see the challenge facing SBR, one need only consider the doctrines tested in the Disutility studies, which admittedly do provide the kind of "individual prevention" benefits that SBR want: three-strikes and other habitual offender statutes, high penalties for drug offenses, adult prosecution of juveniles, abolition or narrowing of the insanity defense, strict liability offenses, and

180 Id. at 123-24. See also supra note 124-25.

181 See supra notes 126-28 and accompanying text.

182 Erica Beecher-Monas, The Epistemology of Prediction: Future Dangerousness Testimony and Intellectual Due Process, 60 WASH. \& LEE L. REV. 353, 387 n.187 (2003) ("Even the most scientific predictions [of violence] based on thorough examination, diagnosis of mental symptoms, past patterns of behavior, and probabilistic assessment are wrong nearly as often as they are right."); id. at 410 ("The most that one can say for any actuarial risk assessment instrument is that it can give a probabilistic estimate of the level of risk for people who share characteristics with the person assessed. And the estimate is subject to a great deal of error."); John F. Edens et al., Predictions of Future Dangerousness in Capital Murder Trials: Is It Time To "Disinvent the Wheel?, 29 LAW \& HUM. BEHAV. 55, 55 Abstract (2005) (reviewing a number of studies and concluding that "clinical assertions that a defendant is likely to commit future violent acts appear to be highly inaccurate and ethically questionable at best").

183 MODEL PENAL CODE: SeNTENCING $§ 1.02(2)$ reporter's note cmt. e (Tentative Draft No. 1, 2007) ("[A]ny attempt selectively to incapacitate high-risk offenders must acknowledge that there will be substantial numbers of 'false positives' - individuals who register as dangerous on even the most sophisticated risk-assessment instrument, but who in fact would not reoffend as predicted.").

184 As to the unfairness problems, see supra note 106. 
felony murder all give the system greater control over potentially dangerous people, but they also dramatically conflict with empirical desert and, as the Disutility studies show, they significantly undermine the criminal justice system's crime-control effectiveness. ${ }^{185}$

No doubt we are saved from additional minor frauds by Mr. Rummel's life imprisonment under three strikes, but given the damage that such cases do to the system's moral credibility and given the crime-control costs shown to follow from this, it is not at all clear that "individual prevention's" crime-control benefits exceed "individual prevention's" crime-control costs. Indeed, one might well assume just the opposite: that the crime-control benefits from avoiding crime by a single detained offender will be outweighed by the crime-control costs in lost moral credibility that single case of unjust detention signals to the thousands or millions of people who hear of the case.

SBR may well want to distance themselves from that particular case (Rummel), and perhaps even from some kinds of three-strikes statutes. But such habitual offender statutes are a central mechanism for assessing "punishment" in SBR's proposed scheme, which under the guise of criminal justice seeks to focus so heavily on an offender's dangerousness.

SBR claim that their new studies support their "individual prevention." ${ }^{186}$ But as Part II shows, nothing in their studies even approaches such support. SBR also claim that their studies show that many of the subjects support the structure of their general approach. For example, they refer several times to the "broad ranges favored by many of our subjects," ${ }^{187}$ as if their subjects' support for the broad sentencing ranges that their indeterminate "individual prevention" system calls for, means that subjects support their "individual prevention" approach. ${ }^{188}$ Not only does subject support for broad ranges not suggest subject support for "individual prevention," but the former notion - that subjects prefer broad ranges - is sheer fantasy.

Recall that some subjects may have "favored broad ranges" as they did simply because the only other choice given to them in Study 7A was a narrow range that may well have excluded the sentence they wanted to give. SBR concede this problem themselves, ${ }^{189}$ and tried (unsuccessfully) to solve it in Study 7B (only to give up and try a different approach in Study 7C). But by the time they reach the concluding sections in their paper, all that is forgotten, and the fantasy of lay preference for broad sentencing ranges has reappeared.

SBR's larger error here is to think that lay persons have any meaningful preference on such structural matters. Lay persons do not know enough about how the criminal justice system works to know the implications of broad versus narrow ranges,

185 Disutility of Injustice, supra note 22, at 1949-78, 1995-211.

186 SBR, supra note 2 , at 79.

187 Id. at 122.

188 See, e.g., id. at 80 (suggesting that Studies 6 and 7 show people "prefer indeterminate over determinate sentences"); id. at 118 (suggesting that Studies 6 and 7 show that "[l]aypeople are willing to consider sentences that are not tied to a particular level of culpability"); id. at 114 (entitling Study 7 as follows: "To what extent do laypeople prefer dispositions focused on prevention rather than desert?"); id. at 120 ("[M]ost people are willing to change their assessments of punishment from what empirical desert would dictate if they think that preventive goals can be achieved through different means. Laypeople appear to believe that utilitarian considerations are at least as important as desert factors in fashioning sentences in the typical criminal case."); id. at 92-93 ([W]hen people make decisions about relative punishment they are ... willing to consider relative risk [and] relative treatability.").

189 Id. at 116. 
or most other procedural or structural issues. ${ }^{190}$ Trying to draw conclusions about such matters is like trying to give meaning to your plumber's or your florist's views on the best way to organize an economy or to configure a tax system. They might well give an opinion, but it would be difficult to know what it really means without knowing how much, if anything, the person knows about the choices available and the implications of each choice.

If SBR are to show that their "individual prevention" is better than empirical desert, as they claim, they must do more than fantasize about lay persons' preference for their abstract rules and structures and must do something to show that "individual prevention" provides greater crime-control benefit than its crime-control cost in deviating from desert. Yet, in his 2011 preventive detention article, Slobogin surveys the data and concludes: "The import of these findings is that the efficacy of indeterminate sentencing conducted consistently with the principles set out in this Article is unknown. More localized study is essential."191

\section{Conclusion}

Ours is not an a priori argument. If SBR had given significant reason to doubt the conclusions of the empirical desert research program or to favor their own "individual prevention" distributive principle, we would have welcomed those results. However, as we show, this is not the case. Significant methodological problems make drawing reliable conclusions from SBR's studies precarious, at best, but, as we show, to the extent conclusions can be drawn, empirical desert emerges unscathed and arguably even more robust and firmly supported than ever before.

There is an enormous amount of preventive effect contained in an empirical desert distribution of liability and punishment. To attempt to exceed this inherent amount requires deviating from empirical desert, producing the outrages documented in Disutility. Three-strikes and other habitual offender statutes, high penalties for drug offenses, adult prosecution of juveniles, abolition or narrowing of the insanity defense, strict liability offenses, and felony murder have all been shown in Disutility to be serious deviations from empirical desert that can be and have been justified on preventive grounds. Each one reflects the judgement that we ought not be content with the preventive effect already inherent in doing justice and instead ought to press for more, even if it means doing injustice.

This is the dangerous thinking that SBR press. It is dangerous because any marginal increase in preventive effect may be an illusion - SBR have yet to show that our existing capacity to predict future criminality and to avoid false positives can produce a more efficient preventive system. And, even if a shift to preventive detention

190 Nor is there any evidence to suggest that people care about a system's structure for its own sake. They have strong feelings about unjust or insufficient punishment amounts, which can affect the system's moral credibility. They may have some general sense of unfair procedures, which can affect the system's "legitimacy." But there is no evidence to suggest that they have an investment in one structure or another for its own sake, apart from the injustice or unfairness that it in fact produces.

191 Slobogin, supra note 147, at 1171. Moreover, in their most recent article, SBR ultimately concede that none of their research "directly test[s]" the claim that empirical desert offers better crime-control utility than their proposed system of individual prevention. SBR, supra note 2, at 120 . 
could gain some marginal increase, SBR have yet to show that such an increase would exceed the documented crime-control costs of doing injustice. Any apparent short-term gain may be washed out by the system's long-term loss of moral credibility, thereby reducing or eliminating the system's social and normative influence.

Admittedly, we are only now beginning to understand the social and normative dynamics at work and to measure their effects. But in our current state of limited sophistication, our best refuge is in doing justice. Even if we do not know the full extent of desert's crime-control benefits, we can at least have the assurance that we are doing no crime-control harm, and no injustice.

This is the judgement that the ALI made in its recent adoption of limiting retributivism, which allows the use of the traditional coercive crime-control mechanisms of deterrence and incapacitation of the dangerous, but never allows them to conflict with desert. The deontologists approve of this restraint, of course, but so too should good crime-control utilitarians, given the state of our current information.

Despite their claims to be following a sort of limiting retributivism, what SBR propose is to turn limiting retributivism on its head. They would look almost exclusively at preventive factors - actually just one factor, dangerousness - and take account of desert only when the costs of failing to do so become too extreme. The American Law Institute, in contrast, sets desert as an inviolable first principle that can never be violated under any conditions, no matter what the crime-control cost.

If one is to "put desert in its place," as SBR's article title seeks, it should be to put it first, as the A.L.I. has done, not last, as SBR propose. 